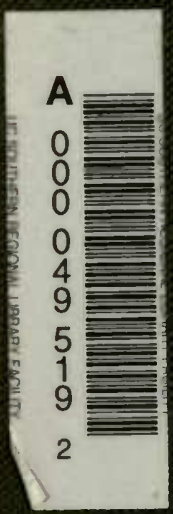

\title{
AN INTRODUCTION TO
}

VEGETABLE PHYSIOLOGY WITH REFERENCES TO

THE WORKS OF DE, CANDOLLE IJNDLEY ETC. 
84

B



\section{PUBLICATIONS OF \\ W ILLIAM PICKERING,} 177, PICCADILLY.

HE Works of John Milton in Verse
and Prose. Printed from the Original Editions.
With a Life of the Author by the Reverend John
Mitford, in Eight Volumes, 8vo. uniform with the
4l. 4 s. Editions of Herbert and Taylor, price

A Residence in Algeria; by Madame Prus. Translated from the original Manuscript, 8vo. $12 s$.

[Just published. "It is thoroughly well worth reading."-Examiner.

Visiting my Relations, and its Results ; a Series of small Episodes in the Life of a Recluse. Fcp. 8vo. 6s. Second Edition. [Just published.

"We have not lately read a volume of this kind with greater relish. Calm sense, quiet humour, and a nice perception of character, distinguish it in no common measure."-Athenceum.

Reminiscences of Thought and Feeling, by the Author of "Visiting my Relations." Fcp. 8vo.6s.

[Just published.

Essays written in the Intervals of Business. Fifth Edition. Fcp. 8vo. 5 s.

The Six following by the same Anthor,

Companions of my Solitude. Fcp. 8vo. 6s. Third Edition. [Just published.

Friends in Council ; A Series of Readings and Discourse thereon. 2 vols. fcp. 8 ro. 12s. A new Edition. [Just published.

The Claims of Labour. An Essay on the Duties of the Employers to the Employed, fcp. 8vo. second Edition, with additional Essay, 6s.

The Conquerors of the New World and their Bondsmen, being a Narrative of the principal Events which led to Negro Slavery in the West Indies and America, Vol. I. post $8 \mathrm{vo} .6 \mathrm{~s}$.

$$
\text { Vol. II. just published, } 7 s \text {. }
$$

King Henry the Second. An Historical Drama. fcp. 8vo. 6s.

Catharine Douglas. A Tragedy. Fcp. 8vo. 5s. 
Of the Imitation of Jesus Christ. Translated from the Latin Original ascribed to Thomas à Kempis. By T. F. Dibdin, D. D. A New Edition, 8vo. 9s, with Frontispiece, ' Ecce Homo,' engraved by Robinson, after a. Painting by Guercino.

Kempis.-De Imitatione Christi, et contemptu Mundi, omniumque ejus vanitatum, Libri IV. Codex De Advocatis Seculi xiii. With Life by Charles Butler. A New Edition, $24 \mathrm{mo}$. price $5 \mathrm{~s}$.

The Life of Thomas Ken, Bishop of Bath and Wells. By a Layman. 8vo. with Portrait, A second Edition in the press.

Bishop Ken's Approach to the Holy Altar. Edited by the Author of the "Life of Bishop Ken." Fcp. 3vo. 2s. 6d. purple cloth, red edges.

Bishop Ken's Exposition of the Apostles' Creed. Uniform with the above.

[Nearly ready.

- Complete Works of George Herbert in Verse and Prose. With his Life by Izaak Walton. In 2 vols. demy $8 \mathrm{ro}$. handsomely printed by Whittinglam, $1 l .1 s$.

This Edition is printed with large type, and intended for the Library. Copies may be had in appropriate bindings.

The Same, 2 vols. fcp. 8vo. 5s, each Volume.

The Poetical Works of John Milton; with a Life of the Author. By the Rev. Jonn MItrond. Uniformly printed with the Library Edition of George Herbert's Works. 2 vols. demy 8vo. 1 l. 1 s.

* Copies may be had in various styles of binding.

Taylor's Rule and Exercise of Holy Living and Holy Dying, in 2 vols. demy 8vo. 1l. 1s. Uniformly printed with the Library edition of George Herbert's Works.

The Same, 2 vols. fcp. 3 vo. 5s. each Volume.

Bishop Taylor's great Exemplar of Sanctity and Holy Life, described in the History of the Life and Death of the ever blessed Jesus Christ the Saviour of the World. 3 vols. fcp. 8vo. 13s. $6 d$.

The Pilgrim's Progress from this World to that which is to come. By John Bunyan. Uniformly printed with the Library Edition of George Herbert's Works. 8vo. 10s. 6d.

English Alice. A Poem, in five Cantos. By Alexander John Evelyn, Esq. Fcp. 8vo. 4s. 
177, Piccadilly.

Festus, a Poem. By Philip James Bailey. Post 8vo. 8s.6d. Fifth Edition.

Poems, by the Hon. Julian Fane.

Our New Parish, its Privileges and Progress. [Nearly ready.

By Harriet E. Fourdrinier. Authoress of "Hints for Happy Hours." Fcp. 8vo.6s. [Just published.

Affghanistan, A Poem. By Thomas Anson. Fcp. 8vo. 4s.

[Just published.

Democritus in London, with the Mad Pranks and Comical Conceits of Motley and Robin Good-Fellow; to which are added notes festivous, \&c. by the Author of "Merrie England in the Olden Time," "Modern Dunciad," \&c. fcp. 8 ro. $6 s$.

The Poetical Works of the late Thomas Lovell [Just published. Beddoes (including “Death's Jest Book"), with a Memoir. 2 vols. fcp. 8 ro. $12 s$.

[Recently published.

"The book is a masterpiece of poetry-a perfect study of style for a young poet. We will commend it to the rising generation of genius."-Examiner.

Tales of the Mountains; or, Sojourns in Eastern Belgium. 2 rols. fcp. 8 ro. $12 s$.

[Recently published.

"The conversations, the descriptions, the incidents, fall into that mixture of the essay and the novel which distinguished the tales of Washington Irving."-Spectator.

Eastbury. A Tale, By Anna Harriet Drury, Authoress of "Friends and Fortune," a Tale; \&c. \&c. One thick volume, fcp. 8 vo. 8 s. $6 d$.

"To any who want to know what goes on in English village life in the days of Queen Victoria, we would say, amongst other books, read Miss Drury's tale of "Eastbury." "

\section{Literary Gazette.}

Bourne's (Vincent) Poetical Works, Latin and English, with Life of the Author, edited by the Rev. J. Mitford. Fcp. 8vo. 5 s.

Poems, by Sir Henry Wotton, Sir Walter Raleigh, and others; edited by the Rev. John Hannah, late Fellow of Lincoln College, Oxford, fcp. 8ro. 5 s."

Shakespeare's Plays, in one beautifully printed by Corrall, 1l. 1s. With 38 Engravings from designs by Stothard, \&ce. $2 l$. 2s. A few Copies printed
entirely on India Paper, $4 l .4 s$. 


\section{Publications of W. Pickering.}

Pickering's Aldine Edition of the Poets. Price $5 s$. each volume, in cloth boards, or $10 \mathrm{~s} .6 \mathrm{~d}$. bound in morocco by Hayday. Each author may be had separately; or complete sets, 53 volumes, price $13 \mathrm{l}$. $5 \mathrm{~s}$. in boards.

Akenside.

Beattie.

Burns, 3 vols.

Butler, 2 vols.

Chaucer, 6 vols.

Churchill, 3 rols.

Collins.

Cowper, 3 vols.
Dryden, 5̆ vols.

Falconer.

Goldsmith.

Gray.

H. Kirke White.

Milton, 3 vols.

Parnell.

Pope, 3 vols.
Prior, 2 vols.

Shakespeare.

Spenser, 5 vols.

Surrey and Wyatt, $\underline{2}$ rols.

Swift, 3 rols.

Thomson, 2 rols.

Young, 2 vols.

"A complete collection of our Poets, witlı well written Memoirs, and good readable type is a desideratum; and from the works sent forth we feel assured that the Aldine Edition will supply the want."-Athenaum.

Bacon's Essays and Wisdom of the Ancients. Edited by Basil Montagu. Fcp. 8vo. 5s.

Bacon's Advancement of Learning. Edited by Basil Montagu. Fcp. 8ro. 5s.

Bacon's Novum Organum, or True Suggestions for the Interpretation of Nature. Fcp. 8vo. 5s.

A short and plain Instruction for the better understanding of the Lord's Supper; with the necessary Preparation required. By the Right Rev. Thomas Wilson, Lord Bishop of Sodor and Man. Fcp. 8vo. 4s. Beautifully printed in large type by Whittingham.

Sacra Privata. The Private Meditations and Prayers of the Right Rev. Thomas Wilson, D. D. Lord Bishop of Sodor and Man. Fcp. 8ro.4s. Uniform with the above.

Lanceloti Andrewes, Episcopi Wintoniensis, Preces Privatæ Quotidianæ. Gr. et Lat. A New Edition very carefully corrected. Fcp. 8ro. 9s.

Bishop Andrews's Private Devotions, with his Manual for the Sick, translated from the Original Greek, by the Rev. Peter Hall, fcp. 8vo, with Portrait, 5 s.

The Sacred Poems and Private Ejaculations of Henry Vaugnas. With a Memoir by the Rev. H. F. Lrte, fcp. 8 ro. 5 s.

"Preserving all the piety of George Herbert, they have less of his quaint and fantastic turns, with a much larger infusion of poetic feeling and expression." 

No. VI.

A BRIEF VIEW OF GREEK PIHLOSOPHY

FROM THE $A$ GE OF SOCRATES

TO TIIE COMING OF

CHRIST.

No. VII.

CHRISTIAN DOCTRINE AND PRACTICE

IN THE SECOND CENTURY.

No. VIII.

$\Lambda N$ EXPOSITION OF VULGAR AND COM-

MON ERRORS ADAPTED TO

THE YEAR OF GRACE

MDCCCXLV.

No. X.

will be published in Decmber. 


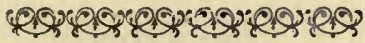

\section{Small Looks on Great Subjects.}

\author{
EDITED BY A FEW WELL WISHERS
}

TO KNOWLEDGE.

$$
\text { No }
$$

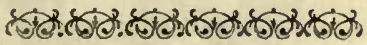




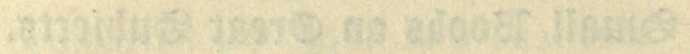

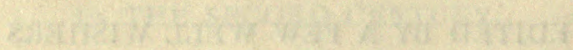

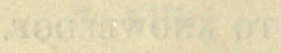
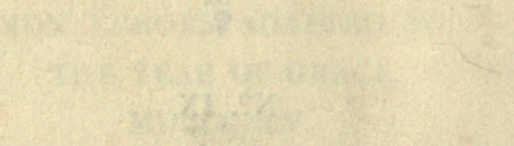

. Mas a 


\section{AN INTRODUCTION TO}

\section{VEGETABLE PHYSIOLOGY}

\section{WITH REFERENCES TO THE}

WORKS OF DE CANDOJIE.

LINDLEY ETC.

ค

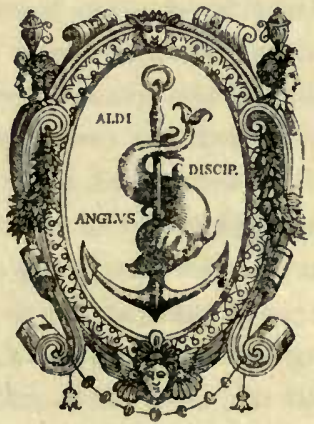

LONDON

WILLIAM PICKERINC; 


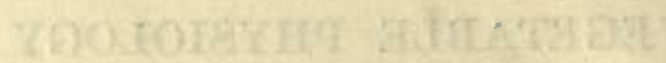

CIIISWICK:

IRINTED BY C. WHITINGIA.M. 
TF a person whose life, from infancy to man1 hood, had been passed in some volcanic island, where scarcely a lichen covered the rock, should be suddenly removed into a region of luxuriant vegetation, his wonder and admiration could not fail to be excited by the scene around him. The return of spring would indeed appear to him as an "annual miracle," and he would probably inquire earnestly into the causes by which the vernal leaves and flowers were produced. Habit has so familiarized us with these beautiful objects, that many of us forget to bestow a thought upon them; and we eat our bread, wear our linen, or sail the ocean in our majestic vessels, without a recollection of the growth of the corn, the flax, or the oak. In this, as in many other matters, King Solomon has set us a wiser example. Monarch, statesman, and philosopher as he was, he nevertheless found leisure to make himself acquainted with "every plant," "from the cedar of Lebanon to the hyssop on 
the wall ;" and "a greater than Solomon" vindicated the claim of this exquisite part of the creation to be studied and admired, when he declared that the Monarch of Israel, "in all his glory," was not arrayed like one of the lilies of the field; while at the same time he instructed us how to draw from the study its most consoling. and important inference, that "if God so clothe the grass" his fostering love will assuredly be bestowed in full measure on us, his rational creatures.

There is one point of view from which the acquaintance with any of the works of creation assumes its highest moral aspect, God is Truth ; the one only source from which no error ever flows; and whenever we have arrived at the undoubted knowledge of any facts in nature, we have made a fresh approach to truth and to the "Fountain of Truth." Let the subject of inquiry be what it may, this assertion will be found to hold good. What God has not disdained to make, we may surely think it time well bestowed to examine, and coming to that examination in a right spirit, we may indeed find "tongues in trees," and even in what man, in his insolence, has called the meanest weeds. 
In one of the former "Small Books" some insight has been afforded into the wonderful chemistry perpetually going on, in the vegetable as well as in the animal department of the great laboratory of nature. It is the object of the present little treatise to give a general idea of the structure, nourishment, and reproduction of the plants themselves; - of Vegetable Physiology in short, -and although the compass of this work is too small to admit of much technical detail, it is hoped that enough information may be conveyed to increase the interest with which its readers will henceforth view the vegetable world around them, and to excite a wish in those who may have leisure to pursue the subject at some future day.

The following Treatise makes no pretension to originality, being a compilation chiefly from the works of M. de Candolle, Alphonse de Candolle,-sometimes almost literally translated,Professor Lindley, \&c. carefully put together with a view to afford an enlarged idea of the general nature of the subject, and to justify the assertion of the first named physiologist, that from the apparently humble functions of vegetable life, we may raise our thoughts to the contemplation of 
the universal order that exists in the natural world.*

Let us now return to our imaginary personage, who has inhabited a volcanic island destitute of vegetation, and has been supplied with food for both man and beast from elsewhere. He has seen rocks, and locomotive, sentient beings, and nothing else. He quits his island, and lo! the earth is covered with grass, and trees, and flowers, and fruit, whose use soon becomes apparent from the myriads of living creatures which find their food there,-but what is this new appearance? Is it the rock shooting up into crystals under the influence of the sun and rain, as salt crystallizes from sea water? But the rock, when broken, retains its characteristic forms and substance unchanged; our islander pulls a herb or cuts a branch, he finds moisture exuding from it, like blood from the flesh of an animal; and the uprooted, or cut portion withers and decays. It has then, in common with the animal, some interior mechanism for the transmission of fluids, and some principle by which

* To the recent works of Dr. Carpenter on Animal and Vegetable Physiology, and to Professor Henslow's "Principles of Descriptive and Physiological Botany," the writer thankfully acknowledges much obligation. 
this mechanism is regulated: for though not one particle of the severed portion be injured by the cutting off from the tree, it can exist no longer than while it forms part of an individual; and the mechanism which nourished it is useless when removed from the influence of that individual principle : this principle is something distinct from mere tubes and fibres, and its operation appears closely to resemble what is called life in animals. Our inquirer therefore will soon resolve that the vegetable is more nearly allied to the animal than to the rock, and he will ask himself again, what is the difference between the rooted animal and the rooted regetable? Is not the vegetable, the lowest grade of living beings, akin to the coral and other such tribes of animal plants? He will find an organism resembling in many cases the lower kind of animals, vessels transmitting moisture upwards, and carrying it downwards,-while others are charged with the supply of air: and the fibres and cellular tissue are formed from the circulating liquid, as the muscle from the blood. The substance of the vegetable, when cxamined chemically, affords fibrine and albumen, the components of blood: its ultimate elements are mainly the same as those of animals, i. e. oxygen, carbon, hydrogen; 
and nitrogen, the residue of ashes alone affording a small portion of other elements, chiefly alkalies. Is there then auy real difference between the non locomotive animal and the non locomotive plant?

For a long time the answer to this question was in the negative, and the world heard of the links of the chain all through nature, the vegetable, the animal, and the intellectual kingdoms blending like prismatic colours, so intimately, that it was impossible to mark the boundary. But our inquirer, with the aid of modern research, will not allow himself to be influenced by theories, however plausible; he will expect to have the means of proof ere he acquiesces in any scientific view, and he will soon perceive one marked difference between the plant and the animal; for the root of the former is furnished with organs for the reception and assimilation of nourishment, while that of the latter is a simple means of attachment to one spot; and the nourishment, instead of being derived from the rock on which it is fixed, floats to the mouth or mouths of the rooted zoophyte, and is of a totally different nature. The plant feasts on unorganized matter, imbibed in a fluid state by the roots and leaves, and never collected into any common receptacle; 
the animal requires organized matter in a solid state, which is received by a mouth into a stomach, where it is reduced to a semifluid mass ; and not till then does the process of assimilation begin. The distinction is broad and clear, and our inquirer will now go on to admire the beautiful mechanism by which the rock, disintegrated by the action of the air, and dissolved by the rain, passes into the vessels of the plant, and there becomes organized, so as to fit it for the stomach of the animal; where it undergoes still farther changes; and finally, produces an organ fitted for the use of a higher order of beings : for it cannot now be doubted that the brain, which is the finest product of animal organization, never is fully called into action till it becomes part of an individual of a yet higher grade. The potass, \&c. of the volcanic rock is in great measure inert till it passes into the absorbent vessels of the plant, and the plant is of no use in creation further than it supplies the nourishment for sentient organism, and the use of the sentient organism, finally, is only demonstrated when a fresh agent is introduced, and the intellectual Will crowns the fair work of Creation.

To an observer such as is above described, 
that link of the chain which connects man with the rock will have a deeper interest than the mere examination of any mechanism, however curious, could inspire: for the announcement that man is formed from the dust of the earth has a deep truth in it which modern science alone can fully appreciate. It is from this dust, that, after the various chemical combinations effected in the cells and vessels of plants and the inferior animals, man derives his corporeal frame, and is, in fact, as far as that portion of his nature is concerned, part and parcel of the earth he moves on ; the first step, therefore, in this extraordinary metamorphosis well deserves a careful examination.

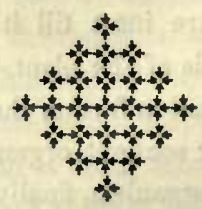




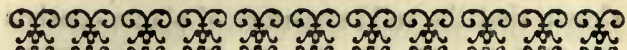

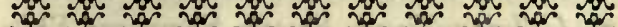

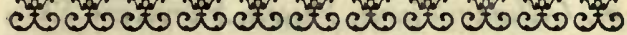

\section{VEGETABLE PHYSIOLOGY.}

\section{CHAPTER I.}

STRUCTURE AND PROPERTIES OF VEGETABLE TISSUE.

1.

VEGETABLE Structure - " chemically composed of oxygen, hydrogen, and carbon, to which nitrogen is always superadded," * consists, in common with that of all organized beings, of

1. The matter which forms the actual substance of the plant itself.

2. One or more liquids, either contained in, or secreted by, its organs.

3. Other substances, more or less solid, deposited during the passage of those liquids through the different portions of the body.

The researches of modern investigators, aided by the improved powers of the microscope, have

* Lindley's Elements of Botany, p. 1. 
shown that the solid structure of plants consists of, Cellular Tissue, Vessels, Fibres, and Skin.

2. Cellular Tissue (contextus cellulosus), is a membranous tissue, very similar in arrangement and form, to a honeycomb, being composed of detached cells, as its name denotes, which are closed, and adhere more or less nearly together-it is found universally in all plants, and many of the lower tribes, such as lichens, mosses, \&c. are entirely formed of it. It surrounds the vascular parts so that in the vegetable as in the animal conformation, no vessel is ever exposed and bare. The diameter of the cells, or vesicles, which is perhaps their more correct appellation, varies considerably, from the thirtieth to the three thousandth of an inch; their shape also is much diversified, but the normal form appears to be round, and it is probable, indeed almost certain, that the variety depends on the pressure of one part of the plant on another during its growth. The resicles seem to originate from a point, called by modern writers a cytoblast,* which sometimes continues visible after they have reached maturity. The property of uniting firmly together, pos-

- Probably from xúros a cavity or hollow point, $\beta \lambda a 50 \varsigma$ a branch or sprout. 
sessed by the cells which compose this tissue, forms a very important part of the history of vegetation, for it is to these adhesions in the cellular tissue, that all the seams in the various organs of a plant are owing. The term parenchyma is applied to the cellular tissue, considered as a mass, to distinguish it from those parts which abound in vessels. Cellular tissue " is self productive, one cell not only having the power of generating another on its surface," but cells frequently produce others, - generally in a definite number,-within their own cavities, on the complete development of which, the parent cell generally perishes or is re-absorbed.

3. Vessels, or Vascular Tissue. This term is applied to tubes, nearly or quite cylindrical, which are observed in the greater number of plants. They are now usually distinguished as Spiral Vessels and Ducts.

A. Spiral Vessels, or Tracheæ, resemble a ribbon which has been rolled round a cylinder, and which by its spiral convolutions forms a continuous tube. These vessels are very apparent in the young shoots of plants, particularly those which can be readily broken without tearing, such as the rose, \&c. They are formed in the medullary sheath (27) in the nervures of leaves, 
\&c. ; but are usually wanting in wood and bark, and are never seen in any of the lower tribes of plants. Their diameter varies from the three hundredth to the three thousandth of an inch.

B. Ducts are transparent tubes, the sides of which are marked with rings, bars, or transverse streaks. They differ essentially from Tracheæ by being inelastic, and incapable of unrolling. They are found in the wood of phænogamous plants, and of Ferns and Lycopodiæ.

4. "The office of all the ducts is the samethat of conveying fluid. It is only in the true spiral vessel that we find air." * And even here at certain periods of the existence of a plant, fluid has also been found by recent observers; though if a branch be cut asunder whilst in a

- Carpenter's Elem. Veg. Pliys. p. 66.

"The functions 'of the Ducts' have not been accurately determined. It is probable that they act as spiral ressels when young; but it is certain that they become filled with fluid as soon as their spires are separated." (Lindley's Elements of Botany, p. 6.)

"There are some large Ducts which appear to bave originated from cells, which bave been placed together end to end, and whose partitious have been so broken down as to form one continuous tube. These are the largest vessels (if they may be truly so considered) in the whole vegetable fabric, and are of the class called "dotted ducts:'-through them the sap principally rises." See Dr. Carpenter's Vegetable Physiology $-\$ 84$, et 
soft state, no juice is ever seen to issue from the orifice of a spiral vessel; and though, as the lymph is found to ascend in the stalks of mosses, \&c. which do not possess these vessels, we may probably conclude that they are not requisite to the transmission of fluid, though occasionally so employed.

The Laticiferous Tissue consists of very delicate and anastomosing tubes, principally occurring in the young bark, and on the under sides of young leaves. They convey the fluid called Latex, or proper juice; which constitutes the nourishment of the young organs, and in which a curious oscillation of globules is visible in the bright sunshine, with a powerful micros: cope.*

seq. - The line of demarcation between the form of the true spiral vessel, and some of the ducts, is sometimes difficult to find ; in some vessels there are obscure traces of spiral form, interrupted in places, and covered by membrane.- "In Ferns, (which have no true spiral vessels) we find Ducts, which very closely approach the spiral vessel in character, having an unbroken coil of spiral fibre throughout their whole extent; but besides the important difference that these ducts are long, continuous tubes, they are further distinguished by the brittleness of the spire, which snaps when we attempt to unrol it." Ibid. $\$ 82$.

- For a further account of this and other local circn. lations, see Appendix (A). 
5. Fibres and Layers. When a branch of a vascular plant is cut transversely, a certain number of points are observed, which are of a more compact character than the rest of the structure. If the branch be divided lengthwise, we shall perceive that these points are the ends of so many longitudinal threads, which will separate from the rest of the tissue more readily than they will themselves break. These threads are called fibres. With a microscope we can see that each fibre is composed of bundles of vessels, bound up and intermixed with cellular tissue. If we macerate the branch in water, after some time the fibres separate of themselves, as in the case of hemp, flax, \&c. This separation in reality disorganizes the vegetable structure; the water first dissolves the softer parts, i. e. the true cellular tissue, and so releases the fibres which it held together, and if the process be continued, the disorganization proceeds still farther, and a homogeneous pulp alone remains, as is seen in the manufacture of paper, where the fibres which had formed the thread are artificially torn and reduced to a pulp, in which, however, a good microscope will still shew us the remains of a fibrous structurc. This description of the structure of fibres explains why 
they are more difficult to break across than to rend asunder lengthwise, this is what workmen call following the grain of the wood. These fibres constitute what is termed Woody Tissue, or Pleurenchyma. It is also found in the young bark, and in the nervures of leaves, "and gives strength to the vegetable fabric." * When many fibres are distributed circularly round an axis, whether real or imaginary, the whole together is called a Layer. It is thus that the annual rings of Dicotyledonous trees are formed.

6. Skin, called also Cuticle, or Epidermis. The whole surface of the plant, wherever it is

* " $A$ peculiar form of woody fibre is found in the stems of resinous woods, especially the Pine and Fir tribe. The diameter of its tubes is much greater than that of any other woody tissue ..... it is by a peculiar set of dots, seen along their course, that these woody tubes may be readily distinguished from all others..... Whatever be their character, they are of great interest as tending to establish the true nature of coal.

"That this substance had a vegetable origin has long been generally admitted; but from the comparative frequency and perfection, with which the remains of Ferns occur in it, it has been supposed to have been produced by the decay of vast forests of this tribe of plants. As Ferns do not form resins however, this hypothesis would not account for the large quantity of bituminous matter which coal contains; and bence it was supposed that 
exposed to the air, with the single exception of the stigma, is covered by this membrane, which may generally be separated from the rest of the tissue, and is seen under the microscope to be formed of a range of flattened cells, distinct from those of the Parenchyma.

7. Stomata, or Pores, are exceedingly minute oval-shaped orifices, capable of expansion and contraction, which are easily visible with the assistance of the microscope on the cuticle . of the herbaceous surfaces of plants. They exist more or less in all the leafy surfaces of vascular plants, but are wanting in all roots, in old stems, in fleshy fruits, and in all the organs

coal must have been formed from resinous woods, even though the remains of such were very scanty and imperfect. Now on applying the microscope to transparent sections of such fragments of coal as most distinctly exhibit the fibrous structure it is seen that they present the character which has been described, as peculiar to the resinous woods - the glandular form of woody fibre, as it has been technically termed, and hence it is established beyond doubt that the immense masses of coal which now contribute so much in every way to the comfort and social improvement of the human race, are but the remains of vast forests, probably the growth of many successive centuries, which chiefly, if not entirely, consisted of trees of the Pine and Fir kind." (Carpenter's Veget. Pbysiology, pp. 65, 66 . 
of cellular vegetables,-with the exception of certain mosses, in which recent observers have detceted them,--and are rarely found in seeds. These stomata are distributed at nearly equal distances; their principal use appears to be that of effecting the aqueous transpiration, a view of their office which is strongly confirmed by the facts that they are very abundant in those plants with membranous leaves which transpire freely, and wanting in those which transpire little; and that they are closed during darkness, when no transpiration takes place, and open in sunshine, when it is most copious. It is probable that in addition to these visible stomata, the superficies of plants may be studded with other pores, too small to be detected by the highest powers of the microscope, and whose existence is only suspected in consequence of physiological phenomena - for instance, if a portion of a plant, known to be devoid of visible stomata, is exposed to the air, it gradually loses weight; and consequently the liquid it contained must have found some exit.

8. Spongioles are certain exterior portions of vegetable tissue, which, without offering under the microscope any appearance of a peculiar organization, have a very strong disposition to 
imbibe moisture, and seem to act like small and very absorbent sponges. The radical spongioles are situated on the fibrous extremities of the roots, and it is by these extremities only that the absorption of juices by the roots takes place.* Senebier placed two roots in such a manner that in the one the extremity alone touched the water, while the whole surface of the other root was covered by it, except the point, which was out of the fluid: the former took up water in the ordinary manner, the other imbibed no sensible quantity. The root fibre and its spongiole may be well observed in the common duckweed, in which it hangs from the under surface of every leaf. Spongioles are found on the stigmas and on the seeds of plants.

9. The name of Lenticular glands has been given to a peculiar kind of spots observed on the

* Dr. Carpenter, in his Vegetable Physiology ( $\$ 106)$, mentions a strong instance of the practical value of an acquaintance with the nature and structure of the spongioles, in the removal of some vines from Shropshire into Norfolk, which was effected without the smallest injury to the plants by first digging a treach round them at such a distance as included all their roots, and then removing the earth " not with spades and trowels, but with the fingers; every fibril being thus uncovered without injury." The vines bore an abundant crop in the following season. 
bark of trees. These spots are in the first instance oval lengthwise, then round, and afterwards transversely elongated. They present a remarkable and very smooth surface, as if the cuticle were dried up : they often become swollen, and end by splitting asunder. Below the cuticle is a substance, sometimes green, sometimes white, which appears to be composed of detached cells, in the form of egg-shaped bladders. It is from these organs that such roots are put forth, as shoot from branches, whether spontaneously, or when plunged in earth; they may with truth be called root buds. They differ from the ordinary buds which produce leaves or flowers, both by their form and position: they absorb nothing from without, as the spongioles do, nor do they appear at all to serve the purpose of evaporation, like the stomata.

10. Glands, in the animal economy, signify those organs which have the power of elaborating some peculiar fluid from the nutritive juices of the body. The word preserves the same meaning when applied to vegetable anatomy.

11. Hairs (pili, villi).--Vegetable hairs are prolongations of one or many cells, which by their length rise above the surface: they are principally glandular and lymphatic; the former 
being the supporters of separate little glands, and the channels by which the fluid secreted by a gland passes off. It is worthy of remark, that in all glands furnished with excretory hairs, the juice secreted is of an acrid nature, and is only directed towards the exit prepared for it, when the gland, pressed on by some exterior force, suffers the fluid to escape; the juice then flows through the exeretory eanal, which by its pointed extremity punctures the skin of the animal which has incautiously touched the plant, and deposits its fluid beneath it. This defensive organization closely resembles the structure of the venom bag and tooth of serpents, and is well illustrated in the common nettle. Lymphatic hairs are mueh more abundant than the preceding; they are of very various forms, and are only found on those parts of plants which are exposed to the air. Their office is probably that of preventing evaporation in certain portions of the plant, and of proteeting the more delicate organs against cold, moisture, insects, \&c.; and in support of this view of their use, it will be found that the tender bud is often defended by these hairs, which, when the shoot approaches to maturity, either drop off entirely, or become thin and widely scattcred.

12. Air Cavitics. The cellular tissue is often 
distended in such a manner as to form cavities filled with air. They are sometimes composed of large cells regularly arranged, in which case they are essential to the species, as in waterplants; in other instances they are merely occasioned by the distension of the cellular tissue.

13. Articulations and Dehiscences. At certain parts of a plant, the cells or vessels instead of being, as usual, dovetailed together, so as to afford the greatest strength, are all arranged in one plane, and consequently easily disunited; at these points, called articulations, all parts of plants which naturally fall of, as the leaves of deciduous trees for example, separate; where these articulations do not exist, the parts may. perish, dry up, and be destroyed by degrees, but are never detached entire. The surface left exposed by the fall of the organ which was attached to the plant by such an articulation, is called a cicatrice or scar. Dehiscence consists in a determinate and regular rupture, such as takes place when fruits, arrived at maturity, burst open (the beech-mast, for instance); the lines which mark the direction these separations will take are often rather prominent, and may be observed before the ripening of the part-the term suture has been applied to them. 
14. Two grand classes are obvious on considering the foregoing organography, viz. Cellular and Vascular plants. The first being wholly composed of cellular tissue, the last of both cellular tissue and vessels. Vascular plants may again be divided into two principal kindsthose whose vessels and cells extend longitudinally, and whose growth takes place towards the centre of the stem; which from this circumstance have been termed Endogenous : * and, secondly, those which have vessels or bundles of elongated cells, taking either a longitudinal or transverse direction, and in which the growth is always towards the circumference of the stem-these are called Exogenous. $\dagger$

15. Having shewn what the general structure of plants is composed of, without reference to those particular organs on which their growth, nourishment, and reproduction depend, it may here be desirable to give some idea of the properties inherent in vegetable tissue, before the organs, which are modifications of that tissue, and of course partake of its properties, are more especially noticed.

Organized beings are, like all other bodies,

- From $\varepsilon \nu \delta o \nu$, within, and $\gamma \iota \gamma \nu 0 \mu \alpha t$, to produce.

+ From $\varepsilon \xi_{\omega}$, without, and $\gamma \bullet \gamma \nu 0 \mu \alpha$. 
subject to the laws of physical and chemical action; we must therefore inquire, in the first place, concerning every fact of their existence; whether it is merely a consequence of those laws, or whether that consequence be modified by the structure and condition of their organization. The first case will come under the class of simple chemical or physical facts; the other will range itself among those which are denominated properties of tissue; that is, properties which are not indeed strictly vital, but which arise from the peculiar structure of living bodies. Other facts, which we cannot include under either of the above heads, are the direct consequences of that mysterious state called life. The distinction of these three classes is the basis of all true physiology.

16. Vegetable tissue possesses three properties which deserve attention, viz. Extensibility; Elasticity; and the power of imbibing moisture. 17. Extensibility. All organic tissues have in a greater or less degree the power of extending themselves even in the act of growth. This property is greater in proportion as the tissue has received fewer solid deposits, diminishes as it becomes older, and at a certain period ceases altogether. If we watch the development of a 
branch, we shall find that its cuticle stretches during a considerable period, after which it breaks, and is replaced by an epidermis: the same thing occurs in all cases in which we can follow the growth of any organ; and if plants appear to increase indefinitely, it is because fresh organs are perpetually added to the former ones, and the older parts fall sooner or later into that inert state in which they are no longer capable of extension.

18. Elasticity of vegetable tissue is that property by which each membrane is enabled to resume its proper position when deranged by any external force. It implies a certain degree of rigidity, and is consequently less sensible when the tissue, having received but few deposits, is still in a semi-fluid state, than when it is of older growth. This property is worthy of remark, because it occasions certain movements, which might be mistaken for vital action. It is very variable in intensity. Every one must have observed that a branch, if bent out of its natural course, returns to it of itself; but in certain cases this is not so-the dracocephalum-moldavicum has pedicels which may be turned from their natural direction, and will remain in that which has been forced on them. The plant, on account 
of this deviation from the ordinary law of elasticity, has been called cataleptic. The elastic movements of plants are sometimes determined by ${ }_{4}^{*}$ an arrangement of the organs, which once deranged, although spontaneously, have nevertheless no power to return to their original state; thus the four stamens of the parietaria tribes have their filaments turned inwards before flowering; but as this process advances, and the filaments enlarge, a moment arrives when they no longer adhere together, but burst open with considerable force: this is facilitated by the tubercles which are formed in the inside of the filament; the anthers, shaken by this sudden movement, scatter their pollen, the filaments die, and the phenomenon can never be repeated. All these effects are consequent on the manner in which the parts are arranged, which indeed is connected with the life of the plant, but must not be confounded with those movements which are really dependent on vital action.

19. The power of imbibing moisture exists in hoth organic and inorganic substances; thus deliquescent salts, as they are called, are so eminently hygrometric, that their own particles are in the end dissolved in the water they have imbibed. 'The effect cannot be carried to this extent 
in organized bodies, being limited by their nature; thus hair, whalebone, \&cc. though capable of being employed to indicate the state of comparative dryness or dampness of the air, from their power of attracting moisture to a certain extent, are nevertheless, under ordinary circumstances, insoluble in water. It is the same with several vegetable productions, which can, consequently, be similarly employed. Vegetable tissue is in general more hygrometric in proportion as it is less loaded with extraneous substances: the woody fibre is, in this respect, very different from the bark; this latter being scarcely hygrometric, while the woody fibre imbibes moisture with great facility. This absorption of water occasions an enlargement of the woody portion, which thus presses itself, as it were, against the bark, and it is in consequence of this pressure, that the gums contained in and under the bark of certain trees are foreed outwards, as in the cherry, plum, \&c. Senebeir has greatly exaggerated the effects of this power in attempting to account by its agency for the ascent of the sap, and for some of the most important phenomena of vegetation. The fact, that the sap ascends in plants which live in water, and that it does not rise in dead plants, might alone prove his theory to be erroneous. 
20. "Connected with the hygroscopicity of vegetable membrane, we may here mention a property* of all membrane, which has probably a considerable influence in the economy both of animal and vegetable life. When a membrane is viewed under the highest powers of the microscope, it appears to possess a perfectly homogeneous texture, without pores of any kind; and yet water, milk, and other fluids, placed under certain circumstances, are capable of passing through it with considerable facility. 'The condition required for producing this effect are these:-Any two fluids which exert a mutual affinity towards each other, being placed on opposite sides of a membrane, their immediate intermixture will commence, each of them passing through the substance of the membrane. If, for instance, a little treacle be enclosed in a piece of bladder, and this immersed in water, a portion of the treacle will soon be found to have exuded, while a still larger quantity of water will have penetrated into the bladder; and this action will continue until the fluids have acquired the same density. The remarkable circumstance attending this phenomenon is the fact of the lighter

* This property is called Endosmosis. 
filid having penetrated the membrane with greater velocity than the denser fluid." (Henslow's Principles of Botany, p. 159-60.)

21. Vegetable existence has been supposed to possess three vital properties, so termed from their analogy with the powers similarly named in the animal economy; viz. 1. Excifability. 2. Irritability, and 3. Sensibility: by the first is understood that peculiar state of the vegetable tissue, which enables it to resist decomposition by water much more energetically while living than after death, and which also renders it capable of supporting the action of air and heat during life, in a manner totally different from that in which their agency affects it afterwards. Many phenomena common to all plants concur to prove that this difference is inexplicable without the admission of vital excitability; such are the rapid mounting of the sap in the living plant, compared with the slow absorption of water in the lifeless tissue; the influence of light on the ascent of the sap, \&c.

22. The quality to which the term Irritability has been applied by some physiologists, is that by which certain portions of some plants respond to the agency of external objects, in a manner somewhat similar to the sudden contraction of 
the muscles in the animal body; for example, when the base of the stamen of the Berberis is pricked with a needle, it is seen to depress itself towards the pistil. If the hairs of the Drosera are irritated, they press themselves close to the leaf ; and one instance, especially, must be familiar to most persons, viz. the closing of the leaves of the Mimosa pudica, or sensitive plant, on the slightest touch. It has, however, been conjectured that all this class of facts may be referred to vital excitability alone; and with respect to the third quality, which some persons have attributed to plants, sensibility, or more properly sensation, until much more positive proof of it shall be adduced than has yet been offered, it can only be classed with those phenomena which are referrible to excitability. The same argument, from analogy, which leads us to suppose that the lower orders of animals are far less sensitive than the higher, is against the idea that plants, wholly unprovided as they are with any apparatus of nerves, can be susceptible of those impressions, whether of pain or pleasure, which in the animal economy we have every reason to refer to a particular portion of the nervous system:-nor can we see in the general order of things any sufficient cause to lead us to 
an opposite conclusion. Although it may be a poetical and an agreeable idea to imagine the whole vegetable world welcoming and rejoicing in the return of spring, and basking in the warm beams that are so congenial to our own nature and necessities, yet the satisfaction this notion might afford would be far more than counterbalanced by the reflection that we could not pluck a rose or gather a peach without inflicting pain; and that the pruning knife was an instrument of torture. One strong reason to conclude against the sensibility of plants, arises from the great contrast between the provision made for them and for animals during the winter. It is known that animals liable to exposure to cold are well defended against it by their fur or down; while trees, stripped bare at the season when all sentient beings look for shelter, would indeed undergo a heavy penalty if they could feel the chill blasts that howl around them.

23. It was formerly supposed that vital excitability was seated exclusively in the vessels, but $M$. de Candolle's reasoning is conclusive against this theory, as he shews that the power is possessed by plants wholly formed of cellular tissue; that is to say, they offer the same facts from which the existence of vital excitability in 
vascular plants has been deduced. The immediate cause of these phenomena appears to be that the cells and vessels of the tissue are endued with a contractile power, analogous to that of the heart in animals, or rather, perhaps, to the contraction and dilatation observed in certain microscopic infusoria: there are cases in which this action (though ordinarily confined to parts so minute as to escape observation) becomes visible: for instance, if a branch of the Euphorbia, or any other milky plant, be cut across, the milky juice exudes from both surfaces. If it flowed by an impulse given either from below or from above, it would only appear on one half of the severed plant; if it issued forth by its own weight by the law of gravity, it could only flow when turned downwards, and if the lower half were held upright,-the fluid would stand as in a cup; but it exudes let the branch be held in whatever direction it may, and it must therefore be owing to some contractile power within.

The agents which occasion or modify vegetable excitability are light, heat, and perhaps electricity; and in addition to these, accidental causes of excitement, such as blows, the action of certain chemical substances, \&c. will in some cases produce the phenomena by which it is manifested. 


\title{
CHAPTER II.
}

\author{
NUTRITION.
}

\section{4.}

TTHE general structure and properties of 1 Vegetable tissue having been explained, it becomes desirable briefly to describe the organs by which plants are nourished, and enabled to perform the functions of growth and secretion, as the physiology of this part of the subject, which is in fact, nothing more than the active agency of those organs, cannot be well understood without some distinct idea of their form and nature.

The organs which are indispensable to the nutrition of all vascular plants, are three, i. e. the Root, the Stem or Trunk, and the Leaves. In cellular plants these are often so united that the parts are scarcely distinguishable. It will be desirable to consider them in detail as they are found in vascular plants, in which they are gencrally well defined.

25. The Root (radix). This term is com- 
monly applied to that part of a plant which is beneath the earth, but this is not an exact definition, as there are roots which exist out of the soil altogether,* it may be more correctly described as that portion which vegetates downwards. The point of junction between the stem and the root bears the name of the neck, or crown :-from this point they proceed in opposite directions, so that the part the nearest to this is, in both organs, the oldest, and in general the thickest. The office of the root is double, it both serves to fix the plant in the soil, and to imbibe its requisite nourishment. Roots are never green excepting at their extremity where it has been shown (8) that they perform their function of absorbing water through their spongioles. As soon as a plant begins to exist, a principal, or tap root, may always be perceived, growing in an opposite direction to the stem:

* Such are the curious braces as they may be called, sent out by the Pandanus, or Screw Pine-this stem is smaller at the bottom than it is above, and as this form is of course unfavourable to the steadiness of the plant in the ground, it sends out roots at various distances up the stein which find their way into the earth, and thus act as buttresses for its support. Such is also the well known method by which the Banyan, from a single tree becomes a grove. 
it is very remarkable in the sced, and is there called the radicle; this principal root, after having sent out branches in all directions, often perishes, and the ramifications frequently take a horizontal course. Besides affording nourishment by direct absorption from the soil, the roots are often storehouses of nutritive matter. Such are those of the Dahlia, which abound in starch, the orchis, \&c. \&c. such roots are generally much swelled or thickened. In their anatomical structure roots principally differ from stems by the absence of stomata, and, in the Exogenes, by the want of a central pith or medulla (27).

26. The Stem (caulis). This organ is never really wanting in vascular plants, though in some it is hidden beneath the earth. "The stem is produced by the successive development of leaf buds (35), which lengthen in opposite directions." The stems of Exogenous plants possess the most complicated organization, but as they are much better understood than those of the Endogenous and Cellular tribes, and as the Exogenes comprise all the trees of our own part of the globe, they are more interesting to us.

Four distinct parts are observed in Exoge- 
nous trees-the Pith, or Medulla, in the centre; the Wood surrounding the pith; the Bark which envelopes the whole, and the Medullary Rays, which run horizontally across the wood and bark, from the centre to the circumference. To these may be added the Medullary Sheath which is but the first annual layer of wood.

27. The Pith, or Medulla, is composed of cellular tissue, whose cells are large, regular, and spongy, it contains starch which is afterwards converted into mucilage," and its office seems to be that of nourishing the young buds; when this function is performed it perishes. Around it is the Medullary Sheath which differs from the succeeding annual layers only in having its vessels usually capable of being unrolled, and consequently truly spiral, it envelopes the pith like a case, and its fibres often branch into the substance of the pith itself, where they appear as scattered spiral vessels. The medullary sheath has been supposed to be the channel by which oxygen, liberated by the decomposition of carbonic acid, is conveyed to the leaves.

* See "Introduction to Practical Organic Chemistry," p. $49, \$ 36$. 
28. The Wood immediately surrounds the central pith, and is formed of concentric layers of vessels, or ducts, and of fibre, annually deposited outside each other. It consists of two parts, namely :

1. The central layers which are harder, more coloured, and evidently older than those near the circumference: these form what workmen call the heart of the wood, and naturalists, true wood, or lignum.

2. The external layers, which being incompletely formed, are softer, whiter, and younger than the former, and constitute what is called the Alburnum.

In some trees, especially in those which are not very hard, the line of demarcation between the true wood and the alburnum is not very perceptible; in the hard woods it is well marked, both by texture and colour, as in ebony, in which the wood is jet black and the alburnum white.

Every layer both of the wood and alburnum, if we except the medullary portion, is composed of vessels and fibres intermixed with elongated cellular tissuc. The sole organic difference between the wood and the alburnum, is, that in the former, the interior of the cells and perhaps 
of the vessels, is encrusted, while in the latter it is empty or only filled with juices scarcely solidified. M. Dutrochet has proved that the different degrees of hardness between divers woods, and between the wood and the alburnum, is owing to the nature of the juice contained in their tissue, and not to the tissue itself, which is identical in both. The tissue of the box and the poplar, though these woods differ so much in density, become perfectly similar when the matter they contain has been dissolved out by nitric acid. The spaces which after maceration appear to exist between the woody layers, are not really such; but were filled with cellular tissue, analagous, for each annual layer, to the central pith of the first year's growth. Each woody layer, being, in the Exogenous trees of cold or temperate climates, the produce of one year, the number of concentric zones in a transverse cutting of a stem will show the number of years during which that part of the tree has existed. To know the entire age of the tree itself, it must be cut exactly at the crown, since of course the higher portions of the stem were not in being when the deposits on the lower were formed, An inscription graven on the trunk of a tree, and penetrating to the 
Alburnum, becomes covered by. new woody layers, and may be discovered unaltered: thus Reisel found in 1675, some capital letters in the centre of a beech tree.* The nourishment of the tree being entirely "performed by the young or sap wood (the alburnum) is carried on when age and decay have deprived it of its heart wood. Thus we see the hollow trunk of an oak or willow capable of sustaining large branches and putting forth foliage almost as luxuriant as when in its prime.

29. The cortical system (or Bark) of Exogenes is organized in a manner analogous to that of the central, or ligneous system-every stem acquiring a cortical, as well as a ligneous zone annually; but while each fresl woodly layer is deposited on, and externally to, that of the year before, each layer of the bark is pro-

- There is a singular illustration of the manner in which the older portions of a stem are completely enveloped in the later deposits of woody matter, to be seen in a part of the stem of the Wellington Tree, presented to the British Museum by Mr. Children. A chain had been passed roand the trunk when it was a sapling, and was so entirely buried in the layers of succeeding years, that it was only by the violent resistance the chain made to the tools of the workmen who were sawing the tree, that its existence was discovered. 
duced on the inner side of that previously formed. The younger and more flexible portion is called the Liber, and is deposited on the alburnum of the wood; the older layers are pushed outwards, and are the cortical layers, or true bark : they represent in the bark, what the heart wood is in the central portion, but with this great difference, that the woody layers being deposited beyond each other in the order of their formation, remain perfectly entire; while the layers of bark, acquiring fresh zones from within, undergo considerable distensionthus, although the number of cortical layers equals those of the wood, their fate is very different: those of the bark, distended by the growth of the tree after the first year, always present more or less flexuous fibres, and this tendency augments with age, while on the contrary the fibres of the wood continue straight and rigid. The woody layers remain in the state of alburnum till they have acquired their proper hardness, - the layers of bark on the contrary, soon lose their freshness, and never attain the same degree of solidity. The first, placed beyond the reach of atmospheric influence, preserve the appearance of life; the latter, exposed to the action of the air and light, 
soon dry up and split. This* difference in the mode of growth accounts for the different results of such experiments in this part of the tree, as were before mentioned as having been tried in the wood-if an inscription be made on the bark only, the letters without lengthening, gradually become thieker, larger, further apart, and are at last effaced. The secretions of a plant are often deposited in the bark.

30. The Medullary Rays, formed of compressed parallelograms of cellular tissue, connect the centre and circumference of the trunk : they strengthen the tissue, and convey secreted nutritive matter in a horizontal direction. They are distinctly perceptible in a section of a woody stem. Sometimes they can be traced from the central pith to the extreme circumference, but ordinarily the line is interrupted.

31. Stems vary extremely in appearance in different plants-sometimes they run under the ground, and are improperly called creeping roots; occasionally they lie prostrate, and send roots into the earth underneath them; - the

- It will be therefore ohserved that, strictly speaking, it is the woody portion only of Exogenes to which the term applies, as the bark follows the laws of the Endogenous tribes. 
term rhizoma is then applied to them;-and sometimes they are much swollen, and called a tuber; - or if they (or rather their leaf buds) (35) thicken below the ground, a corm. All these forms of stem have been called roots; but there are two marked distinctions between these and true roots. They have what are termed nodes, which are the points at which the leaf buds are formed, as well as leaf buds, which are never found on roots properly so called. Scales being the rudiments of leaves, no proper root can be scaly.

32. The stems of Endogenous plants, considered generally, have as their common characters.

1. They are composed of one single homogeneous mass.

2. They have no true medullary channel nor distinct medullary rays.

3. Their older fibres are on the circumference, and the newer deposits in the centre, from which latter circumstance they take their name.

They are less marked in character, and present less regularity of structure than the Exogenes. Thus one species, the Palm, will afford a sufficient idea of the whole class. This stem 
is generally upright, strong, simple, regularly cylindrical, and crowned at its summit with a bunch of leaves : transversely divided, it appears to be composed of scattered fibres, mixed with cellular tissue, which unites them together. At a glance it is obvious that the fibres of the circumference are more close, of a firmer consistence, and older than the inner ones, which are distant, soft, and surrounded by a loose cellular tissue. Each fibre consists of a bundle of tracheæ, and rayed and dotted vessels. The difference in consistence between the circumference and the centre of the trunk is always perceptible, sometimes very remarkable: for instance, there are some palms whose exterior is so hard that a hatchet can make no impression on it, while the inside is a loose spongy tissue, quickly decaying in a humid air. The circumference of the palms corresponds to the wood of our trees, while the centre is a species of alburnum. It is from this central alburnum that the leaves and flowers spring, or in a word, it is from the centre that the development of all the parts takes place. Immediately on the appearance of the plant a first row of leaves is put forth, attached to the crown by a layer of fibres-the next year a second row is produced within the former, and distends them 
-it is the same with the succeeding seasons, till the period when the outer layer having acquired by age the hardness of perfect wood, and no longer admitting of further distension, is incapable of any increase of diameter.

33. A Leaf has two distinct parts-the $P \boldsymbol{P}$ tiole, or stalk, and the Lamina, called also the blade or limb; the former consists of fibres proceeding from the stem, and enclosed in a cellular integument; the latter is formed by the ramifications of the fibres of the petiole, and the expansion of its cellular tissue. In exogenous plants the veins branch in various directions, so as to form a kind of network; in the endogenes they run parallel to each other, and are simply connected by transverse veins. When the petiole becomes lengthened so as to curl up, it is called a tendril, and many curious forms, such as that of the Pitcher Plant, are but expansions of this portion of the leaf. The limb of a leaf presents three distinct parts; the superior and inferior surfaces, and the mesophyllum, or substance contained betwcen the nervures. Both the surfaces are ordinarily furnished with stomata, the under side much more abundantly than the upper; but in leaves which rest by their under surface on the water, this relation is reversed, their upper 
surface (that which is exposed to the air) being alone furnished with stomata. In like manner, leaves which are constantly immersed have no stomata. The nervures of the superior surface are supposed to be the channels by which the juices are conveyed from the stem to the limb; those of the lower surface conduct them back to the bark. If we attempt to twist a leaf so that the naturally superior surface shall be undermost, it endeavours to regain its original situation; and if the force used prevent it from doing so, the leaf quickly perishes.

34. Stipules. This name has been given to small leafy organs, whose only essential character is their lateral position at the base of the leaf. They are occasionally changed into true leaves, and one of them is sometimes wanting; they vary exceedingly in appearance.

35. Leaf Buds are those vital points, surrounded by scales, which are usually found in the axils of the leaves, and from whose growth a branch is formed.* The scales, as the rege-

- "Leaf-buds are always formed from the cellular portion of the stem or branches, on which the function of extending the growth of the individual seems especially imposed. They may be distinctly traced, in young branches, to the pith; and where this has dried up, they may be seen to arise from the medullary rays." (Carpenter's Veg. Phy. p. 197.) 
tation proceeds, are replaced by leaves. When leaf buds are found under ground, and become swollen and large, like the crocus, \&c. they are called bulbs or corms (31). In both cases young bulbs are produced in the axils of the scales, and feed on the old bulb. Some of the latter tribe raise themselves out of the earth by a very curious process. "In some Gladioli," says Professor Lindley, " an old corm produces the new one always at its point; the latter is then seated on the remains of its parent, and being in like manner devoured by its own offspring, becomes the base of the third generation." Leaf buds are divided into regular and adventitious, the former being always found in the axil of the leaves, none of which, in fact, are ever really without them, though in some cases they are undeveloped; so that the arrangement of the branches of a plant would always be the same as that of its leaves, were it not that the buds are very unequally matured : and this regularity is found to exist in reality through every part of a plant, although from the obliteration of some portions, and the non development of others, it cannot always be traced throughout. "It has been distinctly proved, that while roots are prolongations of the vertical or woody system, leaf 
buds universally originate in the horizontal or cellular system."

36. The nutritive organs of cellular plants are far less defined than those of the vascular tribes, and it even appears as if the whole mass of the former were composed of one homogeneous substance, capable of taking diverse forms, and fulfilling different functions, without being separated into distinct organs. They are analogous in many cases to those of rascular plants, but never consist of vessels. They vary so much in the different species of the cellular tribes, such as the Mosses, Hepaticæ, Lichens, \&c. that it would be impossible to describe them here without entering into details far excecding the limits of this work.

37. On considering the phenomena of vegetable nutrition, one fundamental principle mects us at the outset; viz. that no aliment ever penetrates the plant, unless water serve it for a vehicle. Without water there is no vegetation. The first thing then to inquire is how it enters into the system. The habitual and vital absorption of water is performed by the spongioles of the roots (8), although under certain conditions, such as rain, heavy dew, artificial watering, \&c. the surfaces of the leaves have also the power of 
inubibing it. Plants being utterly without locomotion, and unable to seek their own food, it follows that their nourishment must be so abundant in nature as to be almost universally within reach, and so easy of absorption as to offer no resistance to their comparatively feeble powers of action. These necessary conditions are beautifully fulfilled by the spongioles and by the nature of water. 'The spongioles make no selection of healthy material for the nourishment of the plant: and the absorption of fluid through their medium appears to be regulated merely by the readiness with which certain solid substances held in solution can be received along with the water. Thus the action of the spongioles separates a portion of the water from a solution of gum arabic, leaving the gum behind in the remaining solution, in an increased state of saturation; but sulphate of copper in solution-one of the substances most injurious to vegetationis rapidly absorbed. Dr. Carpenter, however, mentions an exception to this, in the power which some plants exert of taking up certain mineral substances which seem peculiarly requisite for them. He says, "if a grain of wheat and a pea be grown in the same soil, the former will obtain for itself all the silex, or flinty matter, which the 
water can dissolve; and it is the deposition of this in the stem which gives to all the grasses so much firmness. On the other hand, the pea will reject this, and will take up whatever calcareous substances (or those formed of lime and its compounds) the water of the soil contains, these being rejected by the wheat." (Carpenter's Veg. Physiol.p. 89.) On this subject Professor Dau. beny has made many curious experiments.

38. Plants, then, absorb water by their roots; but is it pure water only they require? Modern chemistry has decided this question in the negative. Water in its absolute purity, such as we obtain it by distillation, does not exist in nature : if exposed to the influence of the atmosphere it holds some of it in solution; if it is in contact with the soil it will imbibe saline, or organic particles, and thus the water which reaches plants is always more or less charged with other substances.

39. When water, accompanied by the soluble matter it contains, has entered the spongioles, it becomes a part of the juices of the living plant, is propelled forward with great force, and receives the name of sap. This sap rises in the plant, and probably in its course furnishes the air with which the ressels are filled. The rapidity 
with which the sap rises has been proved by several curious experiments. Hales introduced the root of a vigorous pear tree into a glass tube hermetically sealed at the top, with a lute quite impervious itself to air; this tube was filled with water, and placed in a cup of mercury; in six minutes the mercury had risen eight inches in the tube, to replace the water that had been absorbed. From other experiments on the force with which the sap rises, Hales drew the conclusion that it is five times greater than that with which the blood is thrown into the crural artery of a horse. "If a piece of bladder be tied over the surface of a vine stump when the sap is rapidly rising, it soon becomes tightly distended, and will ultimately burst. These effects manifestly bespeak an action very different from the ordinary results of capillarity, and indicate the pressure of a powerful force, a ' $v$ is $a$ tergo,' residing in the lowest extremities of the roots, by which the propulsion of the sap is regulated. Although these results so closely resemble those of endosmosis (20), there still exists a difficulty in connecting the two phenomena; for whilst we may admit the possibility of an interchange between the contents of the vesicles composing the spongioles, and the water in the soil 
which surrounds them, by the ordinary operation of endosmosis, it is difficult to explain how the sap may be propelled forward so violently as it appears to be, in the open channels through the centre of the stem, which contain crude sap of nearly the same specific gravity as water itself. It would be further necessary to account for the manner in which a continued supply of fresh material is obtained for carrying on the endosmosis, which must otherwise soon cease when the fluid within has become much diluted. We shall find, however, that a constant supply of fresh material is actually provided by the direct action of the vital force, during a subsequent period, in the function of nutrition; and hence it is not impossible, though it has not been proved, that both the propulsion as well as the absorption of the sap may principally, if not entirely, be owing to the operation of mechanical causes, dependent, however, for their lengthencd continuance upon the existence of the vital energy by which those conditions are perpetually renewed, and without which the endosmosis would of necessity soon ccase." (Henslow's Principles of Botany, pp. 181-2.)

40. It would seem natural here to observe what course the sap takes in its rise in the plant, 
but the question of the channels through which it is propelled is by no means one to which an indisputable answer can be given. "The great difficulty," says Professor Henslow, "in determining the precise channel through which the progression of the sap takes place, must be ascribed to the perfect transparency of the vegetable membrane, and the extreme minuteness of these organs themselves. By placing a branch in coloured fluids, such as a decoction of Brazil wood or cochineal, they are absorbed and the course of the sap through its whole passage into the leaf may be regularly traced; but on examining microscopically the stains which have been left, it is scarcely possible to feel satisfied whether they are on the outer or inner surface of the vessels and cells which they have discoloured. ..... Since there are many plants which possess no vascular structure, in them at least we must allow the cellular tissue to be the true channel through which the sap is conveyed . . . .... The probability seems to be, that the crude sap rises, at least in woody stems, through the intercellular passages, where it bathes the surface of the cells and vessels, all of which are so many distinct organs destined to act upon it." (Henslow's Principles of Botany, p. 179.) 
Many excellent observers, however, deny the general system of intercellular passages, or of consequence the passing of the sap by these means; the question must therefore be considered as undecided.

41. Heat and light exercise great influence on the ascent of the sap. A plant exposed to the light takes up a sensibly larger quantity of water than one kept in darkness. The leaves exhaling moisture in great abundance (to the amount of about two thirds of the water taken up) and consequently requiring and receiving a proportionate supply, tend largely to promote the direct ascent of the sap, and a terminal bunch, such as is always left by mulberry growers when the leaves are picked, determines the risc of the sap to the top of the tree, whereas if the summit be left bare, the juices will scarcely be active enough to reach it, and in addition to this vertical action, the cellular envelope which surrounds the branches, and which communicates with all the woody and cortical layers by the medullary rays, draws the sap, by the action of the living cellules, in a transverse dircetion. In Endogenous plants, in which there are no medullary prolongations, the sap is necessarily drawn to the summit by the leaves, 
and it is only in youth that the cellular envelope of the branches, can receive a small quantity of moisture: as soon as the action becomes hardened, further lateral growth is impossible. The powerful action of the leaves, \&c. as here described, in determining the ascent of the sap, is a much more probable account of that phenomenon than any propulsive vis a tergo like that supposed in the extract from Professor Henslow in paragraph 39 , to be resident in the lowest extremities of the roots.

42. It is well known that fresh plants exposed to the air part with a considerable portion of their moisture. This exhalation is not performed equally all over the plant, but is in exact proportion to the quantity of stomata on any given part, and it is curious that this fact was established by the experiments of Guillard, Saint-Martin, Bonnet, and Senebier, before the existence of stomata was known. Light has great influence in increasing the transpiration of plants. This exhalation may sometimes be observed in the form of drops of water resting on the leaves, \&c. when circumstances preclude the possibility of their arising from rain or dew. "The manner in which the stomata act is unknown; and consequently we are compelled to 
ascribe the function which they perform to the immediate operation of the vital force." (Henslow.)

43. The influence of the atmosphere on the nourishment of plants, or in other words, their respiration, is the most complicated and perhaps the most important of all the processes of vegetable economy. Animal respiration, which is in effect, that process by which the blood is exposed to the action of the air, may shew us by analogy how necessary it must be to consider the relations of the nutritious juices of this class also of organized beings with atmospheric action in order to comprehend their physiology. Thirty years after Bonnet (then occupied in researches on the uses of the foliage of plants) had first observed that air was given out by living green leaves, Priestley's attention was turned to the subject; and he submitted the air thus obtained to analysis : it proved to be either pure oxygen; or to contain that gas in a much larger proportion than atmospheric air does: other chemists confirmed the details of Priestley's experiments. The phenomenon is evidently connected with the life of the plant, since leaves though still green but no longer living, give out no gas at all until the commencement of decomposition. 
The direct rays of the sun are necessary to the effect: no other light, however strong, will suffice. The course of the phenomena connected with the respiration of plants appears to be the following. The water which enters the plant by the roots contains carbonic acid, which is carried with it into the green parts; it is there decomposed under the influence of the sun's rays - the carbon is fixed in the plant, and the oxygen escapes. The carbonic acid which is formed from the oxygen of the air in all those portions of the plant which are not green, is partly dispersed in the atmosphere, partly dissolved in water, which water at last reaches the plant again, and thus is ultimately absorbed by the roots, drawn up to the leafy parts and there decomposed. The water taken up by the roots holds besides its carbonic acid, a certain quantity of soluble matter containing carbon: this carbon is also carried with the sap into the green parts, it combines during the night with the oxygen which had been previously absorbed by them, and the following day such of this carbonic acid thus formed in the leaves as has not been given out during the night is decomposed by the solar light, as if the carbon could not be usefully deposited in the nutritive juices unless 
it proceed from the decomposition of carbonic acid gas. Thus the whole of this important function, i. e. vegetable respiration, appears to have for its object the fixing carbon in the plant, while the result of animal respiration is to diminish its quantity in the body, or in other words, to supply animal heat by its combustion.* It is well remarked by Mr. Hunt, that "The animal kingdom is constantly producing carbonic acid, water in the state of vapour, nitrogen, and, in combination with hydrogen, ammonia. The vegetable kingdom continually consumes ammonia, nitrogen, water, and carbonic acid. The one is constantly pouring into the air what the other is as constantly drawing from it, and thus is the equilibrium of the elements maintained.

"Plants may be regarded as compounds of earbon, vapour, oxygen, hydrogen, and nitrogen gases, consolidated by the all-powerful, all-pervading influences of the solar ray; and all these elements are the produce of the living animal, the conditions of whose existence are also greatly under the influence of those beams, which are

- See Introduction to Practical Organic Chemistry, p. 61 . 
poured in unceasing flow from the centre of our system. Can any thing more completely display a system of the loftiest design, and most perfect order, than these phenomena?"*

44. It has been shown that the watery juices, pumped up as it were, by the roots, have been drawn to the leafy parts; a large part of the water is there evaporated, green matter is formed, and the decomposition of carbonic acid, ammonia, and water, fixes carbon, nitrogen, and hydrogen in the residuum. From these changes, to which the term assimilation has been given, results the formation of a new and descending juice whose existence is perhaps less palpable than that of the ascending sap, but concerning which there can be no doubt. If a circular incision be made in the bark of an exogenous tree, a tumour will in a short time appear above the wound; this tumour increases, and if the cut be very narrow, it soon reaches the lower lip of the wound, the communication is restored, and the tree lives on as usual, but if the wound be too wide to admit of this junction, the tumour continues to increase till the branch (or the tree, if the main trunk have bcen operated on)

* Researches on Light, p. 200. 
perishes in a longer or shorter time according to circumstances. If the ascending current were impeded, it is obvious the accumulation which causes the tumour, must take place on, or below the lower lip of the incision. This descending sap, or proper juice, - whose chemical composition appears to be water and carbon,-and which itself principally in the form of gum, is capable of being, by very slight modifications, transformed into fecula (starch), sugar, and lignine, quits the leaves during the night, and traversing the bark and pith in exogenous, and the wood in endogenous plants, reaches the roots. In its progress it deposits nutritious matter, which, more or less mixed in the woody portions with the ascending sap, or absorbed with the water which is taken up through the medullary rays by the cellular envelope, is imbibed by and elaborated in the cells. It meets in its course and especially in the bark, glands and glandular cells, which imbibe it and form in their cavities peculiar secretions (51) most of them incapable of nourishing the plant, and destined to be rejected or carried into the substance of the tissue.

The water which rises from the roots to the foliage is almost as pure when it reaches it, as 
at its entrance into the plant, if its course has been rapid through the older wood,* where the particles are slightly soluble; that on the contrary which has traversed those younger portions in which there is much cellular tissue filled with nutritive particles, slackens its course, mixes with and dissolves them, and arrives at the higher parts of the plant loaded with nourishment. The cells appear to be the true organs of nutrition, in which the decomposition and assimilation of the juices takes place. In each cell ligneous matter is deposited which coats its walls, and the inequalities of this deposit in many cases appear to have given rise to the idea that the cells were perforated-the thinner portions being so , transparent, that under the microscope they have the appearance of pores. It is evident from the above detail that there is no circulation in plants strictly similar to that of animals, but that there is an alternate ascent and descent of the sap.

45. It will be gathered from the account of the course of vegetable nutrition just given that

* It has been proved by colouring the water with cochineal, that the ascent of the sap certainly takes place through the ligneous system, though the particular channels may be doubtful. 
the oxygen, hydrogen, carbon, and nitrogen, of which plants are chemically composed (1) are thus derived. The oxygen is abundantly furnished by the decomposition of carbonic acid, by the surrounding atmosphere, and by the water taken up into the system. The carbon, which constitutes so large a part of the texture of plants that it retains the form and character of the species when the other portions have been separated from it, and it alone remains as chareoal,* is also mainly derived from the decomposition of carbonic acid. The hydrogen is partly obtained from the water the plant takes up by its roots and leaves, and also from the same source as the nitrogen, which although so abundant in our atmosphere as to constitute four fifths of its whole composition, does not appear to be thence imbibed in its simple form by plants, but to be supplied to them combined with hydrogen in the form of ammonia, the great ingredient in those animal manures so important in agriculture. "It appears," says Dr. Carpenter, "from recent inquiries, that the

- A remarkable instance of this may be noticed in the triangular pith of the alder used in the manufacture of gunpowder. 
organized tissues of plants, that is, their cells, fibres, vessels, \&c. freed from their contents, are composed of a substance which every where possesses the same composition; and that this consists of 24 earbon, 20 hydrogen, and $100 x y-$ gen, without any nitrogen;" ... “ on the other hand the substances into whose composition nitrogen enters, though very generally diffused through the tissues of the plant, do not seem to undergo organization, but to form part of the contents of the cells, vessels, \&c. of which these tissues are composed. It is eurious to remark that precisely the reverse is the ease with animals; their tissues being composed of a substance containing nitrogen, and substances which are destitute of it being never found in their bodies in an organized state, but only existing there in the cavities of their cells, tubes," \&c. (Veg. Physiology, p. 117, § 163.)

46. It is obvious from the nature of the nourishment which plants require, that the condition of the soil in which they are grown is a matter of great importance. This subject has already been noticed in the "Introduction to Organic Chemistry," which forms the fourth Number of these "Small Books," § 27, \&c. There is scarcely perhaps a stronger proof in 
the history of human progress, of the light which Truth sheds on every thing within its influence, than the improvement that modern agriculture has derived from the science of Chemistry. The earth has been in some sort cultivated from the time when Adam was sent forth to till it, yet not until the last half century,* had the advantages the husbandman may derive from an acquaintance with the composition of the soil of his fields, been known, and little could the landowners of the days in which the alchemist, half empiric and half enthusiast, was preparing the way by his toilsome and blind gropings for the more enlightened researches of his successors, imagine that the time would come when chemistry should, at least metaphorically, teach him how to turn earth into gold. The subject is worthy of all attention, not merely from the pecuniary advantage the scientific cultivator may reasonably expect to gain, but from

- Sir Humphrey Dary, in his first lecture before the Board of Agriculture, delivered in the year 1802, says, “Agricultural Chemistry has not yet received a regular and systematic form. It has been pursued by competent experimenters but for a short time only; the doctrines bave not as yet been collected into any elementary treatise," \&c. 
the mental exercise which he may thus obtain, while labouring in his proper calling. The words of Sir Humphrey Davy in concluding his volume on this subject are admirable: "The same energy of character, the same extent of resources which have always distinguished the people of the British Islands, and made them excel in arms, commerce, letters, and philosophy, apply with the happiest effect to the improvement of the cultivation of the earth. Nothing is impossible to labour, aided by ingenuity. The true objects of the agriculturist are likewise those of the patriot. Men value most what they have gained with effort; a just confidence in their own powers results from success; they love their country better, because they have seen it improved by their own talents and industry; and they identify with their interests, the existence of those institutions which have afforded them security, independence, and the multiplied enjoyments of civilized life." 


\section{CHAPTER III. \\ GROWTH AND SECRETIONS.}

47.

THE progress of the growth of a plant, and 1 the annual course of regetation remain to be considered, but it must be borne in mind, to use the words of Professor Henslow, that "of the precise manner in which the assimilation of nutriment takes place we know nothing, and the first steps towards the formation and development of any organized being are entirely concealed from us." New cells, fibres, and vessels are most undoubtedly formed, or the leaf buds must remain for ever undeveloped, but we are ignorant of the immediate cause, and of the first commencement of the effect; for when we say that the vilal action is excited (whether in the growth and nourishment of a plant or an animal,) what do we more than state a fact, whose course we may indeed follow when we have once observed it, but whose origin is, in the present state of our knowledge, beyond our 
reach?-The course of growth, however, as far as we can trace it, seems to be the following. When a leaf bud begins to be developed, it is seen to be formed of a short axis surrounded by many leafy folds or scales. This axis begins to lengthen; the ascending sap is consumed by the developing leaves, which separate from each other by nearly equal distances, proving that the shoot increases through its whole length. The power of extensibility which is inherent in vegetable tissue, especially when young, is now probably an agent in the growth; - the ascending sap, which is partially decomposed in its upward course, supplies some nutritive matter to the young cells, and, it may be conjectured, stimulates them to that method of increase by the spontaneous formation of one cell on the surface of another, of which mention was made in describing the cellular tissue. The young leaves now begin to perform their office, they exhale water, decompose carbonic acid gas, and the formation of a descending current commences. This descending sap, depositing in its course such nutritive materials as are proper for the formation of wood, gradually solidifies the new shoot. If the ascent of the sap be augmented by placing the plant so that it may ab- 
sorb a large quantity of water, or if the current of the descending sap be materially lessened, as will occur if it is in total darkness, then shoots are obtained extraordinarily long and herbaceous; as in the weeping willow, and in the blanched plants of flax, cultivated for the finest Flanders thread. On the contrary, if the quantity of water be diminished, and the plant exposed to the influence of such circumstances as will increase the fixation of carbon, we obtain shoots which are short, firm, and woody; as are seen in the dry and light situations of southern climates and high mountains. It appears from the above facts that the lengthening of the shoots depends on the influence of the ascending sap, while from the richness of the descending current, and consequent deposition of nutritive matter, arises its solidification and the diminution or cessation of vertical growth. Those plants which have the greatest tendency to form wood, attain proportionately the soonest to that state of hardness which arrests the lengthening of the shoot; thus it is seen that there is a sensible relation between the slowness of increase in height in each tree, and the quantity of carbon which it furnishes to combustion. In herbaceous perennials, the nourishment, 
which would in trees serve to form ligneous matter, is deposited in their roots, as gum, starch, or sugar, and serves to feed the young shoots of the following year. The newly formed branches of exogenous trees do not grow much in diameter till they have attained their length.

48. It cannot be said that the ascent of the sap is absolutely null during the winter, but it is then much weaker than in the remainder of the year. In the early spring two phenomena occur; the heat of the sun begins to be felt on the bark, or cellular envelope, and the more strongly in proportion to the youth of the plant; the vital action is excited, and the sap begins to rise from the roots, whose spongioles, at this epoch of vernal vegetation, rouse from their lethargic state.* Besides this effect, a second occurs, less visible indeed, but highly important: during the depth of winter, the earth has been warmer than the air; this comparative warmth is felt by the roots, in which all the accumulated nourishment

* Perhaps from the circumstance that during the winter the roots being full of the sap, which has been there stored up, are incapable of imbibing more until that begins to rise, which it does as soon as the influence of the sun is felt on the bark. 
of the preceding year remains; $\uparrow$ their vitality is excited, and towards the end of winter radical fibres are formed; these, being fresh and vigorous, begin to act, and pump up moisture from the soil : thus, the revival of vegetation is effected by the concurrence of two causes-the activity of the roots, and of the cellular envelope. The sap arriving at the leafy parts* promotes the development of the buds; it first reaches those at the summit of the branches, either because it moves more readily in a vertical than in a lateral direction, or because the wood and bark of the extremity of the branches, being young and herbaceous, the cclls have there retained a stronger vital action. When the action of the leaves has furnished a certain quantity of nutritive juice, it descends through the laticiferous tissue, supplies the material from which the tissues and secretions of the plant are formed, and which " being poured out between the bark and the newest layer of wood, is the viscid sub-

+ If a bad preceding year has rendered the quantity of nourishment small, the vegetation of spring is proportionably weak.

- If the sap, as it rises, finds any fissure in the wood, it flows from it as from a fountain, as may be observed in what are called the tears of the vine when pruned. 
stance called cambium; in which the rudiments of the cellular tissue that is to form part of the new layer of wood, after a time present themselres. Even if this cambium be drawn off from the stem, its particles shew a tendency to arrange themselves in a form resembling that of cells and vessels; though no perfect tissues are produced by this kind of coagulation." * When this cambium is formed, the tree is said to be in sap. The gradual solidification of the tissues then proceeds, but the leaves continue to take up nourishment, till, after some months of spring and early summer, they are loaded with earthy and carbonaceous particles, and then the buds which are situated at their axils become comparatively more active than the leaves themselves, and now absorb the sap, while the leaf wholly or in part ceases to da so. This effect, taking place before the year is sufficiently advanced to check the second vegetation (or midsummer shoot, as it is called), continues, and fresh branches are developed. At length the leaves in autumn, being too much encumbered with solid matter to retain any activity, cease to perform their functions, and finally die. Then

* Carpenter's Veg. Phys. p. 208. 
if, as has been shewn (13), they are articulated, they fall off; if not, they are destroyed by the inclemency of the air. The leaves of what are called evergreens form no exception, although they endure longer than those of deciduous plants, and instead of all falling off together in the autumn, are renewed at various intervals; yet each individual leaf undergoes the ordinary course of growth and decay. The change of colour which withering leaves present is a very curious subject, and one which the recent experiments of Sir John Herschell and others have tended to explain. Mr. Hunt thus expresses his views of this phenomenon: "The change in the colour of leaves appears to be entirely dependent upon the absorption of oxygen, which all the green parts of plants have the power of absorbing, particularly in the dark. This true case of chemical affinity, it would appear, goes on equally with the spring or the summer leaves, but during these periods the vital force, under the stimulus of light, is exerted in producing the assimilation of the oxygen for the formation of the volatile oils, the resins, and the acids. In the autumn the exciting power is weakened; the summer sun has brought the plant to a certain state, and it has no longer the vital energy necessary for 
continuing these processes: consequently, the oxygen now acts in the same manner on the living plant, as we find in experiment it acts upon the dried green leaves, when moistened and exposed to its action : they absorb gas and change colour." (Researches on Light, p. 201.)

To the fall of the leaf succeeds the dormant wintry state: there is no absorption of moisture from the air, except through the cellular envelope; the roots have not yet formed the young radicles, and are in their least active state; and on account of these concurring circumstances, this is the most favourable period for transplanting.

49. Cellular plants have, as has been said before, no true vessels; their fibres, if they may be so called, are composed only of elongated cells, and are never identical with the ligneous fibre. The formation of the elongated cells, when such exist, determines the direction of the juices ; thus in the mosses, for instance, the stem receives the water at its base, and by its radical fibrils, and transmits it in a longitudinal direction to the leaves, which direction is determined by the elongated cells. These plants are likewise nearly devoid of stomata, and can therefore only exhale the superabundant water slowly, and 
almost imperceptibly, and as a simple effect of the porous nature of the tissue. The nourishment of the cellular tribes appears then to be thus accomplished; the water which reaches them penetrates either at given points, or by the whole surface, and reaches the cells, where it is elaborated by each, separately, in its own cavity.

50. As the blood of animals performs two distinct offices, first, depositing throughout the whole body the materials necessary for the nourishment of each organ; and, secondly, undergoing in certain particular organs, named glands, an operation which is called secretion, and from which results the formation of particular juices; so in the vegetable economy, the sap, besides affording the general sustenance which has been considered above, experiences a peculiar action in certain organs, and furnishes peculiar secretions as the result. These secretions never form any part of the tissue of a plant, and are either excrementitious, i. e. those which are thrown off; or special secretions, which remain, in most cases, where they are formed, and are seldom removed from one organ to another; but in others pervade the whole plant, and, as in the case of Tannin, impregnate the soil around them. The excretions are extremely various, and are probably a provision 
for the removal of some material which is useless or injurious to the plant. One of the most singular is that of the fraxinella, thongh this is probably of the same class with the volatile oils to be mentioned presently. If at the close of a dry, hot day, a light be held near the top of that plant, the vapour which surrounds it takes fire, and burns with a lambent flame, without injury to the plant. This vapour appears to be of the nature of an extremely volatile oil, which escapes from the small glands that cover the surface of the plant, for the white fraxinella, which has fewer glands than the red, exhibits the phenomenon in a slighter degree. Other excretions are acid, some are caustic, some glutinous (such as the leaves of the gum cistus). Some plants secrete a waxy matter from their surface; others saline or saccharine particles. Manna is one of these excretions, it both exudes naturally, and is also obtained when artificial incisions have been made in the tree. It would be impossible to describe, or even enumerate, all the excretions of plants in this treatise, the above may convey an idea of their nature.

51. The Special Secretions are liquids secreted in the bark, or some other organ. Their principal characters are,

1. That they are all composed of two or 
more principles, which can be separated, and are not homogeneous, like the nutritive juice, which, although it may of course, by chemical analysis, be resolved into its elementary constituents, presents no such peculiar principle as do the special secretions.

2. These latter contain (in addition to their carbon) oxygen and hydrogen, not in the proportion in which they combine to form water, but with a preponderance of one or the other of those gases, and some of them, and those the most important to man, also contain azote, i. e. nitrogen.

3. All these secretions, if they are absorbed by the roots of living plants, even by those which produced them, act on them as poisons. A sufficient proof of their not being intended to percolate the plant in the manner of the nutritive juices.

They consist principally of four divisions:1, Milky, and 2, Resinous Juices, 3, Volatile, and 4, Fixed Oils," and the local secretions, properly so called. The milky and resinous fluids, which form the first two classes, are some-

- With the fixed oils should perhaps be classed the vegetable tallows and butters. 
times expelled from the plant by accident or disease, and are almost always eapable of removal from one portion of the plant to another. Professor Henslow gives among the milky juices the following curious instance of a tree called the Cow Tree, from Humboldt: "On the barren flank of a rock grows a tree with dry and leatherlike leaves; its large woody roots ean scarcely penetrate into the stony soil. For several months in the year not a single shower moistens its foliage. Its branches appear dead and dried; yet as soon as the trunk is pierced, there flows from it a sweet and nourishing milk. It is at sunrise that this vegetable fountain is most abundant. The natives are then to be seen hastening from all quarters, furnished with large bowls to receive the milk, which grows yellow and thickens at the surface. Some empty their bowls under the tree, while others earry home the juice to their ehildren. The milk, obtained by incisions made in the trunk, is glutinous, tolerably thick, free from all acrimony, and of an agreeable and balmy smell." The milky juices are contained in the bark and leaves, the volatile oils in closed eells, from which they are probably only exhaled in consequence of the permeability of the tissue, whence it happens that the organs which secrete 
these oils are in general strongly odorous. 'The fixed, or fat oils, as they are called, are formed in cells, from which they never escape by any natural process, but must be artificially extracted. The caoutchouc (India rubber) is an instance of a milky secretion, as are also our common spurge, and opium, the well known product of the white poppy. Most of the juices to which the name of milky has been applied are white, but not all of them, for instance, the lactic secretion of our English celandine is of a brilliant orange colour. Of the resinous juices one example, common resin, is familiar to every one. Of this class are the true balms, Gum Benzoin, \&c. Examples of volatile or essential oils, as they are otherwise called, such as those of the rose, \&c. will readily occur to every one's recollection; and the fixed oils, those, for instance, of the nut, the almond, linseed oil (the product of the seed of the flax), olive oil, so useful for both food and light to the inhabitants of the south of Europe, with many others, are too well known to need more particular notice here. The principal chemical distinction between the volatile and fixed oils is that the former are powerfully odorous, slightly soluble in water, with which they pass over in distillation, communicating 
their flavour to it; and that they are volatilized by heat without decomposition. The fixed oils, on the contrary, are inodorous and insipid, support two or three hundred degrees of heat without volatilizing, and are decomposed at a higher temperature. In a physiological point of view their difference is equally striking. The volatile oils are found in the leaves or in the cortical system, the usual place of the secretions; the fixed oils are either situated in the seeds themselves, or more rarely in the tissue of the pericarp.

52. There are many local secretions, of which a detailed account belongs morc properly to a chemical treatise than to one that, like the present, is only physiological, and also too brief to do more than glance at the other sciences immediately connected with the subject : it will therefore only be possible to notice these secretions slightly here. They consist of acids, such as citric, malic, acetic, \&c. prussic acid (remarkable by the absence of oxygen) which is found in peach and laurel leaves, \&c. of Gluten, Albumen, Tannin and Colouring matter, of which indigo is one of the most important, and a variety of other secretions or principles, each confined to the particular vegetable in which it is found, 
such as Asparagin, whose name denotes its origin from the asparagus.

53. Besides the above, substances are found in plants which are purely mineral, and which are principally lime, magnesia, silica, alumina, and perhaps barytes. Potash and soda are found in very large quantities. Iron, manganese, and copper* have been observed, and besides the above there are occasionally found in plants chlorine, iodine, sulphur, and phosphorus. The reader is referred to No. 4 of these little treatises $\uparrow$ for further particulars on the chemical part of the subject.

54. Those whose leisure permits, and whose inclination leads them closely to examine into the simple yet marvellous chemistry by which compounds, absolutely essential to the animal economy, but which it has no direct power of preparing for itself, are formed for it in the vegetable organism, will perceive how true it is that the more we search into those phenomena which we daily and hourly witness and experi-

- Copper was found by M. Bischoff, Dr. Meissner and M. Sarzeau. See De Candolle, Pby. Veg. vol. i. p. 389.

t "Introduction to Organic Chemistry." 
ence, the more we shall see that nothing has been made in vain, and the more resistless will be the proof that such a chain of causes and effects as may be traced from one end of creation to the other, could only have had their origin in that One Mind to which every thing is ever present, and who, in the very " constitution and course of nature," has stamped too deeply to be effaced, even amid the moral disorder man's folly has introduced, the "image" of his own perfection, and the "superscription" that the work of his hand is "very good." To God then let all "render the things that are God's," by a full acknowledgment of his wisdom and goodness in thus supplying what they need, and by making such a use of those gifts as may best prove their gratitude, and most tend to the glory of the Giver. 


\section{(2) (6) (6) (6) (5) 2 (3)}

\section{CHAPTER IV.}

REPRODUCTION OF PLANTS.

\section{5.}

7 HE reproduction of plants from seed is the 1 chief object of all those wonderful organs, a description of which will now be given, and it would be difficult if not impossible to find in the whole of the beautiful world around us, any thing more admirable than the organization by which that object is attained; while the parts are, in many instances, so minute as to require the assistance of the microscope to discover them at all. It has been said above, that the chief office of that lovely portion of the vegetable kingdom, the flowers which glow like gems in our sight, is to reproduce the species; but it would be ingratitude to assert that they have no other end to answer. The mere purpose of reproduction might doubtless have been effected with no beauty to charm the eye, but it pleased Him who made that exquisite organ, also to 
furnish it with objects that should delight it, and we can scarcely behold these jewels of the field, and not say of them as the son of Sirach did of the brilliant bow whose tints they emulate, "Look on the 'flowers' and praise Him who made them, very beautiful they are in the brightness thereof."

56. Plants are distinguished, with reference to the organs of fructification, into two great classes,-phanerogamic, or those which have their flowers visible to the naked eye, and are more or less symmetrical; and cryptogamic, in which the flowers, if they exist, are invisible except by the microscope, and are little, if at all symmetrical. In the former group the seedbearing and fecundating organs are very distinct; in the latter they are not so.-The first include all the Exogenes, and the greater part of the Endogenes, the second all the cellulares and some of the Endogenes.

57. At a longer or shorter period before a Phanerogamic plant is about to put forth blossoms, points appear called Flower Buds, surrounded like the Leaf Buds above described, by developed or undeveloped leaves, and like them really situated at the axil of a leaf, though that leaf may have been rudimentary and oblite- 
rated,*-these points in due time expand into the perfect flower-and if a transverse section be made of them they will be found to be most exquisitely folded together in the state to which botanists have applied the term astivation.

When the Flower Buds are unfolded and have expanded into flowers, they are seen to be composed of one or more whorls of leaves, surrounding and protecting the organs of reproduction. $t$ In anatomical structure they do not differ from true leaves. Situated immediately within the inner whorls of these leaves, if more than one be present, we find the organs of fructification, the Stamens and Pistils.

58. Each Stamen consists of two parts, the anther, and the filament; the latter is a slender

* The subject of symmetrical arrangement in the parts of a plant is a very curious one, but involves too much technical and botanical detail to be properly in. troduced here. Whether it really exist to the extent that botanists have supposed, or not, there is ample proof that the general law is that of symmetry, and the deviations from it the exceptions: the realer who wishes for detailed information on this point is referred to the 6th chapter ("Morphology") of Professor Henslow, "Principles of Descriptive and Pliysiological Botany."

† If but one whorl exists it is always considered by botanists as a Calyx, whether it be green or coloured,if more than one whorl is present the outer one is always 
stalk by which the stamen is attached to the flower, but is not an essential portion of the organ, and is sometimes wanting; it is formed of spiral vessels, surrounded by cellular tissue-on the top of this filament, or occasionally, though rarcly, sessile on the flower, is the Anther,-a case of cellular tissue, usually consisting of two lobes, which contain the Pollen. This is the indispensable part of the fructifying organ.

59. The Pollen* is a collection of minute cases, "containing a fluid in which float grains of starch and drops of oil. It is furnished with apertures through which its lining is protruded, in the form of a delicate tube, when the pollen comes in contact with the stigma." + The shape

the calyx,-the inner whorls being the Corolla,-while the general term Perianth, is applied to the whole floral envelope together,-any more minute notice of the forms and divisions of the calyx and corolla would be inconsistent with the intention of the present treatise, which does not profess to be an Introduction to Botany.

* Any one who wishes to study minutely the wonderful varieties in form, \&c. of the Pollen will find the subject illustrated by most exquisite microscopic drawings in the German work by Fritzsche ("Ueber den Pollen") and in another in the same language (" Ueber das Polien der Asclepiadeen") by Ehrenberg.

† Lindley, El. Bot.pp. 47, 49, 50. 
of the pollen grains varies extremely ; "its function is to vivify the ovules."*

60. The Pistil occupies the centre of the flower, and consists of three parts; the ovary, the style, and the stigma. "The orary is a hollow case enclosing ovules (or young seeds). It contains one or more cavities, called cells. The stigma is the upper extremity of the pistil. The style is the part that connects the ovary and stigma; it is frequently absent, and is no more essential to a pistil, than a petiole to a leaf, or a filament to an anther." + The pistil, or orarium, is frequently composed of several carpels, (61) each having its separate ovary, style, and stigma.

61. Carpel. The pistil, anatomically considered, is in reality a modified leaf, or whorl of leaves, and a carpel "is formed by a folded leaf, the upper surface of which is turned inwards and the lower outwards; and within which are developed one or a greater number of buds, which are the ovules." $\ddagger$

- Lindley, El. Bot. pp. 47, 49, 50.

t Ibid.

‡ Lindley's Elements of Botany, p. 50 .

Professor Lindley has made the subject of the carpels so clear in his "Ladies' Botany" that it may be well to add his explanation to what is given above. "Next to 
62. The Ovule, as has just been seen, is contained within the carpel, and becomes the germ of the new plant; it is either naked or enclosed in a covering, sometimes sessile, sometimes stalked : in its most complete state it consists of a nucleus, surrounded by two coats or integuments.

63. The Fruit is the mature state of the pistil or carpels.

the stamens, and occupying the very centre of the flower" (the common Ranunculus, or Buttercup, is the one he takes as his example) " are a number of little green grains, which look almost like green scales; they are collected in a heap, and are seated upon a small elevated receptacle; we call them carpels. They are too small to be seen readily without a magnifying glass; but if they are exanined in that way, you will remark that each is roundish at the bottom, and gradually contracted into a kind of short bent horn at the top; the rounded part is the ovary, the horn is the style; and the tip of the style, which is rather more shining and somewhat wider than the style itself, is named the stigma: so that a carpel consists of ovary, style, and stigma. At first sight you may take the carpels to be solid, and, if you already know something of botany, you may fancy them to be young seeds; but in both opinions, you would be mistaken. The ovary of each carpel is hollow and contains a young seed called an ovule, or little egg; so that the carpel, instead of being the seed, is the part that contains the seed." (Letter I. p. 7.) 
64. The ovary of the pistil becomes what botanists call the Pericarp of the fruit; it has a great variety of names, dependant on the number of carpels, their situation, the quality of their texture, \&c.

65. The Seed is the perfected ovule, it is covered with an integument, which is sometimes curiously spread out so as to form wings, and contains the embryo lying in it as the embryo chick is in the egg, and often similarly surrounded by the albumen which affords its nourishment.

66. Spores. The principal organs of reproduction in those plants, called Acrogens or Flowerless, which are destitute of stamens and pistils, are called spores, these are cells which are seen by a microscope to be analogous to a grain of pollen; the cases containing them are termed thece or sporangia.

Sori are clusters of thecæ, and the Indusium is a portion of the epidermis which encloses them.

67. The reproduction of plants is of two kinds, that by seed and that by division, which is either natural or artificial and will afterwards be noticed. When the flower is fully developed, -a period which arrives in different kinds of 
plants at very different times, -in some for instance, in the first, in others in the second year of their existence, - a process occurs by which that contact between the pollen (59) and the stigma (60) takes place, which in all the phanerogamic plants is absolutely essential to the reproduction of the species by seed. This contact or impregnation is thus effected. "The pollen emits a tube of extreme delicacy, which pierces the stigma and style, and passing downwards into the ovary," * thus reaches the ovule. The result of this process is the gradual development of the embryo which becomes the fruit: or, in other words, the pistil, after this impregnation, arrives at maturity, and the ovary of the pistil becomes the pericarp of the fruit. This main fact remains in all cases unaltered, though in consequence of the non-development or obliteration of some of the parts, the identity of the fruit with the original pistil is sometimes difficult to recognize. Various names have been applied to fruits according to their form, nature, \&c.-All, however, are receptacles for the seed, which is the perfect state of the ovule, as the fruit generally, is of the pistil.

* Lindley's “ Elements of Botany," p. 56. 
The provisions for ensuring this necessary contact between the pollen and the stigma, are among some of the most curious in nature. The stamens of many plants, by a spontaneous movement, approach the pistil at the season when fructification should commence. The action of water on the pollen, which would be injurious to it, is in some cases avoided by the corolla closing on the approach of rain, and in aquatic plants the organs of fructification are defended from wet, by being produced in a cavity filled with air, or by the flowers being raised above the surface of the water. The Vallisneria, whose flowers are diæceous (that is, the pistil is situated on onc plant, and the stamens on another) is a very remarkable instance of the method by which the contact of the two organs is effected. It grows in the waters of the south of Europe, strongly cmbedded in the mud by its roots. The pistils are situated in flowers which are on long peduncles, spirally rolled up at first, but which uncurl till they reach the surface. The flowers which bear the stamens have, on the contrary, a very short peduncle, but the buds form littlc bladders, on which they float, detached from their stems, around the 
pistilliferous flowers, they then expand, emit their pollen, and die.

68. The seed itself consists, as has been stated above (65), of an embryo, and of the albumen, \&c. which nourish and protect it. This embryo, " the organized body that lies within the seed, and for the purpose of protecting and nourishing which the seed was created," " consists of the cotyledons, the radicle, the plumule, and the collar." * The cotyledons are those undeveloped leaves which are seen to push their way above the ground when a plant first makes its appearance: they vary in number, but most usually there are either one or two of them. If a plant have but one cotyledon, it is said to be Monocotyledonous, which is the ease with all the Endogenous tribes; if there be two or more, the plant is called Dicotyledonous, in which latter division all the Exogenous tribes are found. The Cryptogamia are all Acotyledonous-that is, without cotyledons.

69. The ascending portion of the embryo plant is called the plumule, and is sometimes hardly distinguishable from the cotyledons; the de- 
scending portion is named the radicle, and forms the future root, \&c.: the collar is the line of separation between them. "When the seed is called into action, germination takes place. The juices of the plant, which before were insipid, immediately afterwards abound with sugar," as in the conversion of Barley into Malt, "which process consists in promoting the germination of the seed by moderate heat and moisture, and checking it by the higher temperature of the kiln as soon as the largest possible quantity of saccharine matter is formed. When the seed has germinated, and sugar is produced, the period of growth commences." This growth is in the first instance caused by the absorption and decomposition of water, whose oxygen combines with the superfluous carbon of the seed, and is expelled in the form of carbonic acid gas. When the absorption of oxygen has removed a sufficient quantity of carbon from the sced, "the young plant begins to absorb food, and to grow by the processes of assimilation and respiration already described;" and as soon as the seed is once active it receives, by a special provision of nature, a larger proportional share of the sap than any other part of the plant. Probably the heat produced by the consumption of its carbon 
is also essential to the welfare of the newly formed plant, and may give the necessary stimulus which brings its organs into action.

70. The fact that darkness is essential to germination has long been known-" an embryo, exposed to constant light, would not germinate at all, and hence the care taken by nature to provide a covering to all embryos in the form of the integument of the seed, or of a pericarp." Mr. Hunt has recently turned his attention to this subject, and he remarks thus on it: "It is not at present in our power to explain in any thing like a satisfactory manner the way in which the luminous rays act in preventing germination. The changes which take place in the seed during the process have been investigated by Saussure : oxygen gas is consumed, and earbonic acid gas evolved; and the volume of the latter is exactly equal to the volume of the former. The grain weighs less after germination than it did before; the loss of weight varying from one-third to one-fifth. This loss of course depends on the combination of its carbon with the oxygen absorbed, which is evolved as carbonic acid. According to Prout, malted and unmalted Barley differ in the following respects: 


\section{Unmalted Malted}

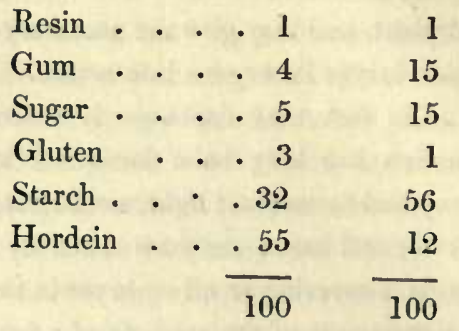

This shows that the insoluble principle, hordein, is, in the process of germination, converted into the soluble and nutritive principles, starch, gum, and sugar. We are therefore at present left in considerable doubt; we can only suppose that the luminous solar rays act, as indeed we find them to do on many of the argentine preparations, in preventing those chemical clranges which depend upon the absorption of oxygen. A like interference has been observed by Sir John Herschell to be exerted by the red rays of the spectrum; and from the manner in which germination is impeded in the seeds covered by deep red media, we may trace a somewhat similar influence." *

All Mr. Hunt's experiments prove " that the

* " Researches on Light," p. 192. 
process of germination is obstructed by the influence of light on the surface of the soil, although the bulbs and seeds have been buried some depth beneath it."*

" One very remarkable result," says Mr. Hunt, " must be noticed ; under all ordinary circumstances plants bend in a very decided manner towards the light. In all my experiments with red fluid media, they have as decidedly bent from it." †

* "Researches on Light," p. 191.

+ Ib. p. 319.

A very curious phenomenon which from its usually taking place in the evening has been called the sleep of plants, appears to be principally owing to the influence of light. The fact itself is, that in certain plants the leares fold up, and sometimes grasp the stem. It occurs also in some flowers which shut up periodically, and the inference that light is probably the agent in producing this effect, was drawn by M. de Candolle from the circumstance that he found the period of its occurrence could be reversed by excluding the light from the plants during the day time, and placing them in strong lamp light at night. (De Candolle, Phys. Veg. vol. ii. p. 860.)

It was remarked in an earlier part of this little work, that the influence which the study of one science has on many others, with which it appeared in the first instance to promise no connection, was illustrated by the benefit that agriculture derires from cliemistry; another proof of 
72. In whatever manner a seed may be placed in the ground, it invariably shoots forth its plu-

the fact that in the observation of natural phenomena, and the rational investigation of their causes, it is impossible to foresee or limit the beneficial results which may follow, even where we have least reason to anticipate them, is afforded by the comparatively norel subject of Photograpliy. This, which at first appeared but an ingenious application of a natural agency to the purposes of art, is assuming, in the hands of some of our greatest philosophers, the rank of a science, which promises to lead to discoveries equally curious and important. The true nature of that sunbeam, whose wonderful operation can either call forth the vital energy of a plant, cause it to perform its functions of growth and nutrition, yet prove detrimental to its germination; or delineate its portrait with a fidelity and beauty unknown to the pencil of man on the sensitive surface presented to it, has yet to be fully ascertained; but that it has other properties than were supposed before the subject of Actino-Chemistry came under the investigation of Herschell and others, seems already established; and who shall assign a limit to the possible results wlich may arise from a clearer knowledge of the nature and operation of such an agent in the universe. It may as yet seem to bear little on the immediate subject of the present work, but it is impossible to assert, that a further insight into the nature of a cause whose effects on vegetation are sodecided, may not prove of great practical benefit; and although its study is no new branch of science in itself, yet the new aspect under which it is now pursued may probably lead to unanticipated Truth. 
mule in an ascending, and its radicle in a descending direction. Invert it as we may, the result will be the same; but on what vital energy within the plant the constancy of this fact depends, seems yet entirely uncertain. Whether it arise from the tendency of upper portions of plants to seek the light, or from any other cause, the reason is equally obscure, and we can hardly reckon on its being ascertained by the most minute investigation; it seems to belong to that elass of phenomena in nature whose ultimate prineiples are too subtle for our grasp, and appear to depend on that vitality which we can indeed perceive most palpably in its effeets, but whose eause is known only to the Creator: whether modern science will be permitted to approximate nearer to the truth on this and some few similar subjects must remain at least doubtful : at all events we are not now in possession of any wholly satisfactory solution of the difficulty.

" That gravity is an important agent in determining the difference between the directions taken by the root and stem, is shewn by an ingenious experiment of Mr. Knight. He placed some French beans on the circumference of two wheels, and so secured them that they could not 
be thrown off when a rapid rotatory motion was given to the wheels. One wheel was disposed horizontally, the other vertically, and both were kept in constant motion while the beans were germinating. The radicles of those beans which germinated on the vertical wheel extended themselves outwards, or from the centre, and the plumules inwards, or towards it. Those which were placed on the horizontal wheel pushed their radicles downwards and their plumules upwards; but the former were also inclined from and the latter towards the axis of the wheel. This inclination was found to be greater as the relocity of the wheel was increased. Now in the vertical wheel the effects of gravity were nullified; since the beans were constantly changing their position with respect to those parts which were alternately uppermost and lowermost, in each revolution. The only cause which could have produced the effects described must be the centrifugal force, which has here replaced the effects of gravity, compelling the root to grow outwards and the stem inwards, instead of downwards and upwards. The effect produced upon the horizontal wheel is evidently the result of the combined action of the forces-gravity inclining the root downwards, and the centrifugal 
force propelling it outwards; and the reverse with regard to the stem. Although it is plain that gravity is the efficient cause in establishing the directions of the stems and roots of plants, it is not so easy to understand the manner in which it produces opposite effects on these two organs. Various theories have been formed to account for this, and the most plausible is that which ascribes it to the different manners in which the newly developed tissues are added to the root and stem. In the root the addition is almost entirely confined to the very extremity, while the stem continues to increase for some time through its whole length. Hence it is supposed that the soft materials continually deposited at the extremity of the root must ever be tending downwards from the effect of gravity alone. (Henslow's Prin. of Botany, p. 292.)

Is it not probable that we may find the agency of light connected with the fact of the plumule ascending?

72. The reproduction of the tribes of the Cryptogamia takes place in a very different manner from that of the flowering plants. In all of them it occurs spontaneously, and without any contact between one part of the plant and another. At the season of the year when the 
lowest tribes of all, such as the Red Snow, the Confervæ, \&c. are to reproduce their species, a number of small granules are liberated by the bursting asunder of the cell which enclosed them. They gradually develope themselves into cells, acquire the size and form of the parent plant, and become distinct individuals capable in their turn of producing others like themselves. The apparatus of reproduction if we may so call it, increases in complexity as it approaches the higher orders, but in all except the cells just mentioned, the immediate organ is called a spore, ${ }^{*}$ and is analogous to the seed of the flowering plant.

73. It has been seen that in reproduction by seed, each germ has the power of becoming developed, after fecundation, into a separate individual plant, entirely distinct from that which gave it birth. In adđition to this accustomed mode of increase, plants are also propagated by

* "It is in the spores that the power of increase resides; every one of them will form a new plant, and consequently they are analogous to seeds, but, as they do not result fron the action of pollen upon a stigma, they are not real seeds, but only the representations of those organs amongst the flowerless plants." (Iindley's Ladies' Bot. p. 270.) 
division; and this is either natural or artificial, and depends on two circumstances: in one, the ascending organs are first developed, or in other words an adventitious leaf bud (35) is produced, and these favour the subsequent development of the roots; in the other, roots are first formed, and by their action promote the development of the ascending system. The former is in general the case when the germ is found surrounded by a sufficient deposit of nourishment to sustain it till it can push forth its roots: this nourishment is furnished by the mother plant from the descending juices. To this sort of buds may be given the general name of tubercles, though botanists designate them by a variety of appellations. In all tubercles a phenomenon occurs which distinguishes their germination from that of seed; in the latter the radicle is always first developed, while in the tuberele the aseending part, - that which corresponds to the plumule,is first put forth. The common potato is an instance of this mode of increase; the tubercles are detached towards the end of the year either by the death of the stem on which they grow, or by the slightest accident, and falling on the ground, vegetation ensues. This single example is sufficient for the present purpose; the 
phenomenon exists in many other plants under various forms. In the cases in which vegetation commences in the descending system, that is, in which roots, whose development is always effected through the descending juices, are first formed, the result is produced in some portion of the stem which is found to contain a deposit of nutritive matter, and which is within reach of moisture. This effect occurs naturally in some stems, but is facilitated by any cause which tends to arrest the nutritive juice in its descent, and so to form an accumulation of it at a given part. Thus in nature when a portion of a stem containing such an accumulation, is buried beneath a humid soil, and has a fleshy bark, it tends to put out roots, which it does naturally by what are called "suckers," and man, profiting by this provision, adopts the method of increasing by layers, pipings, cuttings, \&c. since it is found that the part thus endowed may be separated from the parent trunk, and being composed of the two parts that constitute an individual plant, a stem and a root, is capable of an independent existence. In some instances a leaf planted in the ground will vegetate from its central nervure.

74. There is one great difference notwith- 
standing so much apparent identity, between the products of the two methods of reproduction above mentioned. In the case of propagation by seed, the embryo is really, and from the first moment of its existence, a being distinct from the parent plant, the seed is furnished with all the organs it requires; the tubercle, on the contrary, is but a fragment of the plant that bore it, and has gradually to form for itself the needful organs. The seed, being entirely distinct, may only resemble the original plant by the general characteristics that belong to its kind; while the tuberole or the cutting, being actually portions of the plant itself, preserves its minutest particularities. A very curious instance of reproduction occurs in the lemna, or common duckweed. If one of its little dises be placed in a saucer, we shall soon see it send forth laterally a tubercle which grows in a horizontal direction, puts out a root underneath, and thus forms a second plant similar to the former, but united with it. This double disc continues to vegetate in the same manner, and so on.

75. Besides the method of increase by cuttings, tubercles, \&c. mentioned above, another exists which is, as all gardeners well know, of immense practical utility - that of grafting.- 
All parts of plants have the power of uniting together by their cellular tissue, - thus we see even in those which consist only of cellular substance, that such adhesions take place. The name of graft has been especially given to one case of adhesion, that in which the liber, and particularly pith, of two plants unite so nicely together that the part called the graft can receive its sap, and thus live by the nourishment it derives through the organs of the old plant; thus artificially doing what parasitic plants, such as the mistletoe, do by nature. There is, however, a limit to this operation; if we except parasitical and some few natural adhesions, we shall find that artificially it is only plants of the same natural family that can be grafted together with any thing like permanent success, and only those of families strongly analogous in which any union will take place at all. When they are not of the same family the grafts are of short duration in consequence of their physiological difference from the tree to which they have been united. Grafts are of three kinds - that ordinarily so called, in which a severed portion of a stem is united to another tree, whose bark has been cut away at the proper spot, - that by approach, which consists of drawing two branches 
or two trees together, each remaining in the ground held by its own roots, and taking off the bark of each at the point of contact; the liber and pith of the two plants soon unite by the development of their cambium, and one of them may then be cut away below the junction. The third method is by the insertion of a portion of a stem containing a bud in the axil of a leaf, within the bark of the tree on which we desire to ingraft it; the bud thus inserted reeeives nourishment from the juices of the tree in which it is placed, and is developed as it would have been on the stem from which it was originally taken.

76. There are various subjects of great interest connected with the reproduction of plants, whether from seed or division, but which are too numerous to be dwelt on in an elementary work: among them is the production of hybrid varieties by fertilizing the stigma of one plant with the pollen from another, which may oecur accidentally, if the plants are in each other's neighbourhood, or may be effected at pleasure between those whose natural affinities are very close. In this manner modern gardeners have succeeded in raising numberless varieties of favourite genera. The effect of culture and care 
generally, as is universally known, is to improve the beauty and value of the vegetable productions by which we are so bountifully surrounded. This subject, interesting as it is, can here be only recommended to notice, without further entering on it. Its details may afford to those whose local situation enables them practically to pursue them, an occupation at once healthy to both body and mind, and so connected with chemistry and mineralogy, as to lead on from the simple nurture of a pretty or useful plant, to the study of some of the most important of the sciences.

77. What great antiquity the method of grafting may claim, we may gather from St. Paul's exhortation to the Gentiles in the 11th chapter of his Epistle to the Romans, in which the metaphor is used throughout with an evident knowledge of the subject. Indeed the custom appears to have been one with which practical gardeners have been familiar for ages, and to which attention has been at times particularly turned.

In the Philosophical Transactions for 1675, mention is made of a work by Abraham Munting, printed three years before, which shows that his attention was practically given to the 
cultivation of fruit trees, and to the improvement of the sorts by grafting. "To obtain extraordinary good, large, and beautiful apple fruit," he advises "by all means to graft good grafts upon such apple stocks as are produced from the seed, and have been deprived of their heart root which shoots downuards." *

To the invaluable and long continued investigations and experiments of Mr. Andrew Knight, however, and to his acute reasoning on the subject, the present highly improved knowledge of the best method of grafting trees, and of the general nature of the subject, is mainly owing. In a paper published in the Phil. Trans. for 1795, Mr. Knight gives a very interesting account of the experiments which convinced him of the fact, so important in its practical results, that " every cutting taken from the apple, and probably every other tree, will be affected by the state of the parent stock. If that be too young to produce fruit, it will grow with vigour but will not blossom; and if it be too old, it will immediately produce fruit, but will never make a healthy tree, and consequently never

* Phil. Trans. abridged, vol. xix. p. 192-3, "Account of some new books." 
answer the intention of the planter." Having suspected that the decay in some trees he had seen recently grafted might be the consequence of the diseased condition of the grafts, Mr. Knight says, "I concluded that if I took scions or buds from trees grafted in the year preceding, I should succeed in propagating any kind I chose. With this view, 1 inserted some cuttings of the best wood I could find in the old trees, on young stocks raised from seed. I again inserted grafts and buds taken from these on other young stocks, and wishing to get rid of all connection with the old trees, I repeated this six years; each year taking the young shoots from the trees last grafted. Stocks of different kinds were tried, some were double grafted, others obtained from apple trees which grew from cuttings, and others from the seed of each kind of fruit afterwards inserted on them; I was surprised to find that many of these stocks inherited all the diseases of the parent trees."-Mr. Knight came at last to the conclusion which subsequent experience has fully confirmed, "that all efforts, to make grafts from old and worn out trees grow, are ineffectual," and that "the durability of the apple and pear may be different in different 
varieties, but that none of either would regetate with vigour much, if at all, beyond the life of the parent stock. I am confirmed in this opinion by the books on this subject; of the apples mentioned and described by Parkinson, the names only remain, and those since applied to other kinds now also worn out; but many of Evelyn's still remain (1795), particularly the red streak. This apple, he informs us, was raised from seed by Lord Scudamore in the beginning of the last century. We have many trees of it, but they appear to have been in a state of decay during the last forty years.... ... the durability of the pear is probably something more than double that of the apple." Many of the readers of this paragraph will probably recall to mind the gradual and complete extinction of the unrivalled "Golden Pippin," which has evidently afforded a proof of the truth of Mr. Knight's deductions. His experiments on seedling apples, while the excellence of several of the sorts affords much encouragement to gardeners and landed proprietors to imitate his example, and endeavour to replace by new fruit trees of equal goodness, the kinds whose limit of duration may be pretty nearly guessed, also 
show the necessity in this, as in most pursuits, of the valuable qualities of patience and perseverance which he must himself have possessed in so great a degree, since of the seeds he sowed he reckoned that one in a thousand came up which was not a crab, and one in a thousand of these became a good eating apple.

78. There is one more subject, connected with reproduction by seed, which is too curjous to be passed over; the wonderful tenacity of vegetable life. This, indeed, is shown in the plants themselves in many instances, such as the enormous longevity of some trees, particularly the oak, the yew, and some of foreign growth,* but it secms even more extraordinary as it exists in seeds. The latter will remain torpid for many months or even years without injury. Corn grains enclosed in the bandages which envelope the mummies, are said to have occasionally germinated, though most of them seem to have lost their vitality. There is nothing improbable in the fact; but as the Arabs, from whom the mummies are commonly ob-

- In the Appendix will be found translated a table given by $\mathrm{De}$ Candolle of the presumed age of some celebrated trees (B.) 
tained, are in the habit of previously unrolling them in search of coins, \&c. it is not always certain that the seeds which have sprouted, were really at first enclosed with the mummies.*

* Carpenter’s Veg. Physiol. $\$ 451$.

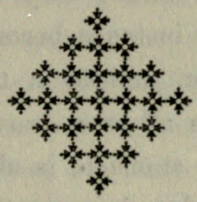


ato

\section{CHAPTER V.}

COMPARISON OF VEGETABLE WITH ANIMAL

PIXYSIOLOGX.

79.

$\mathrm{T}^{\mathrm{T}}$ is impossible to consider the subject of 1 Vegetable Physiology and organization, without being struck by the analogy which it presents in so many points to that of Animals. - Yet, however strong may be that analogy, it never in any instance becomes identity, and the marked fact, noticed in the Introduction, that the latter in all cases convey their food by the mouth to a stomach, is alone sufficient to establish a boundary between them ;* the com-

* There does indeed appear to be one group, about which some doubt exists in the mind of some physiologists as to its reference to the animal or vegetable king. dom. "They are mostly," says Dr. Carpenter, " formed of cells jointed together, as the Confervæ; but some of them seem to possess a different interior structure; and others exhibit very curious motions, which can scarcely be distinguished witl certainty from those of animals." (Carpenter's Veg. Phy. p. 44.) 
parison, however, between the two, is so interesting and instructive, that a few words may be well bestowed upon the subject.

The whole range of functions both of animals and plants, that is to say as far as nutrition and reproduction are concerned, affords ample illustrations of the near approach to similarity in the two kingdoms - a few examples of each may prove the truth of this assertion, while the difference will also in general be equally perceptible. In the entire course of that function by which the individual is nourished, the main point holds good in both cases; i. e. that matter fitted for its food is taken into the system by the appointed organs, thence conveyed through the necessary channels, assimilated and converted into the requisite substance for continuing and replenishing the tissue of the body, and furnishing the needful secretions, while such as is unavailing to any of these purposes, is excreted. In the plant, however, the juices are not conveyed to a single receptacle, there to be elaborated, but, according to the process detailed in the foregoing pages, are gradually in their progress converted from the crude into the nutritive sap. The circulation of this sap, and the power of the glands to convert it into peculiar secretions, suggests immediately to the 
mind the idea of an analogy with the circulation of the blood in animals, and a fanciful imagination might see a degree of further likeness to the venous and arterial blood in the two states of the sap. The similarity, however, though it does exist, is but very partial, no one general circuit of the sap throughout the system, as there is of the blood originally propelled from the heart, really taking place. Again the tissue produced and nourished in the two kingdoms, though very analogous in some respects, is by no means identical:-the cellular texture of animals differing from the cellular tissue of plants by its structure, which is not actually composed of individual cells, united together by the cohesion of their walls, but of "a congeries of extremely thin laminæ or plates, variously connected together by fibres, and by other plates, which cross them in different directions, leaving cavities or cells." * This cellular texture, however, forms the essential material of the animal fabric generally, as the cellular tissue does of the vegetable. The important chemical difference between animal and vegetable organized tissue has already been noticed, viz. the pre-

- Roget's “Anim. and Veget. Physiol.” vol. i. p. 99. 
sence of nitrogen in the one case and its absence in the other (45).

80. Perhaps, however, the most curious and interesting analogy between animal and vegetable organization is that which relates to the process of reproduction-which in some of the lowest tribes of animals approaches more nearly to identity with that of plants than in any other function. In several of the most minute of the Infusoria, in which nevertheless, small as they are, the patient investigation of Ehrenberg has discovered a series of stomachs, we meet with frequent examples of multiplication by the spontaneous division of the body of the parent into two or more parts. "Many species of Monads for instance, which are naturally of a globular shape, exhibit at a certain period of their development a slight circular groove round the middle of their bodies, which by degrees becoming deeper, changes their form to that of an hour-glass; and the middle part becoming still more contracted, they present the appearance of two balls united by a mere point. The monads in this state are seen swimming irregularly in the fluid; as if animated by two different volitions; and apparently for the purpose of tearing asunder the last connecting fibres, 
darting through the thickest of the erowd of surrounding animalcules; and the moment this slender ligament is broken, each is seen moving away from the other and beginning its independent existence." *-Now although we have not in the vegetable world any instance of this voluntary division, yet, in the all but spontaneous action, the reproduction of plants by the division of their parts bears a strong analogy to it, and in the cases to be further mentioned, the resemblance is still stronger. The Hydra, or fresh water Polype, " is capable of indefinite multiplication by simple division: thus, if it be cut asunder transversely, the part containing a head soon supplies itself with a tail; and the detached tail soon shoots forth a new head, with a new set of tentacula. If any of the tentacula, or any portion of one of them be cut off, the mutilation is soon repaired; and if the whole animal be divided into a great number of pieces, each fragment acquires, in a short time, all the parts which are wanting to render it a complete individual." $\dagger$ In this same animal (the Hydra) which is thus capable of being increased by

* Roget, Anim. and Veget. Physiol. p. 583.

+ lb. p. 586. 
what would in a plant be slips or cuttings, the natural method of propagation is analogous to that of many plants - such as the Duckweed: "At the earliest period at which the young of this animal is visible, it appears like a small tubercle, or bud, rising from the surface of the parent hydra; it grows in this situation, and remains attached for a considerable period; at first deriving its nourishment as well as receiving its mechanical support, from the parent.... this mode of multiplication, in its first period, corresponds exactly with the production of a vegetable by buds; .... although at a later stage, it differs from it in the complete detachment of the offspring from the parent." * An instance of reproduction occurs in the sponges, which bears a near resemblance to the spontaneous fructification and bursting of the thecæ of many of the Cryptogamic plants. "The parts of the Spongia panicea, which are naturally transparent, contain at certain seasons a multitude of opaque yellow spots visible to the naked eye, and which, when examined by a microscope, are found to consist of groups of ova, or more properly gemmules, since we cannot

- lb. p. 590. 
discover that they are furnished with any envelope. In the course of a few months these gemmules enlarge in size, each assuming an oval or pear-like shape, and are then scen projecting from the sides of the internal canals of the parent, to which they adhere by their narrow extremities. In process of time, they become detached, one after the other; and are swept along by the currents of fluid, which are rapidly passing out of the larger orifices." * "When two gemmules, in the course of their spreading on the surface of a watch-glass, come into contact with each other, their clear margins unite without the least interruption,-in a few days we can detect no line of distinction between them, and they continue to grow as one animal. The same thing happens, according to the observations of Cavolini, to adult sponges, which on coming into mutual contact, grow together, and form an inseparable union. In this species of animal grafting we again find an analogy between the constitution of zoophytes and that of plants." $\dagger$

81. With respect to the higher orders of ve-

- Roget, Anim. and Veget. Physiol. p. 156.

† Ib. p. 159. 
getable life, the Phanerogamic, or flowering plants, the whole analogy in their method of increase with that of the larger part of the animal creation has been so long known, and so much insisted on, that it is superfluous to dwell on it. Enough has been said to show how the same analogy holds good in the lower tribes; to multiply instances would swell these pages unduly and unnecessarily. The paper "recently read by Professor Forbes, at the meeting of the British Association at York, contains, as far as can be gathered from the abstract given of it in the Literary Gazette, for October 19th, 1844, some very curious information bearing on this branch of the subject. From that abstract the analogy between "the formation of the parts of the flower out of transformed leaves," and a corresponding phenomenon in "one tribe at least of composite animals," seems to be manifested

* "On the Mosychology of the Reproductive System of the Sutularian Zoophytes, and its analogy with the Reproductive System of the Flowering Plants." Prof. Forbes has a paper with a similar title in the 93rd No. of the "Annals and Mag. of Nat. History" for Dec. 1844, and there are some curious observations on the same subject also contained in a paper by Mr. Couch, in the "Annals" for March, 1845. 
strongly in the cases on which Professor Forbes has grounded his novel views of the subject.

Connected also with this part of Vegetable Physiology is a paper of Dr. Martin Barry's, in the Phil. Trans. for 1842 , Pt. 1 ;* in which he traces considerable analogy, not to say identity of form, between animal and vegetable fibre, and especially in one peculiar portion: the following extract will be found interesting. "It is known that vegetable tissue presents, in some parts, a feature which has heretofore seemed wanting, or nearly so, in that of animals, - the spiral form. I venture to believe that some appearances met with in my investigations, may go far towards supplying this deficiency." Dr. Barry has given plates of these appearances as they are found "in the nervous tissue, in muscle, in minute blood-vessels, and in the crystalline lens."

82. The power of vitality, so wonderfully conspicuous in the vegetable kingdom, which enables a seed to retain its vegetating power though dormant for many years, has a remarkable analogy with the revivification of some of the animalcules. "The Rotifer redivivus, or

" "On Fibre." 
wheel animalcule, can live only in water, and is commonly found in that which has remained stagnant for some time in the gutters of houses. But it may be deprived of this fluid, and reduced to perfect dryness, so that all the functions of life shall be completely suspended, yet without the destruction of the vital principle; for this atom of dust, after remaining for years in a dry state, may be revived in a few minutes by being again supplied with water."* Other animalcules exhibit the same phenomenon; and the analogy is still further carried on by the fact well known to gardeners, that seeds which have been long kept, will vegetate more surely if soaked for some time in water before they are planted.

Every discovery in whatever science, seems more and more clearly to point to simplicity of Design and Unity of purpose in nature:Where the same course and method will accomplish a similar end, a different one seems never to be adopted. All the researches of modern physical science, though they may place new objects and new substances within our view, tend to lessen, not enlarge the list of elemen-

- Roget, Anim. and Veget. Phys. vol i. p. 62. 
tary bodies; - and all investigations into the organized parts of creation teach us to refer more and more to a few simple principles, modified, indeed, by the nature and requirements of each species, but all pointing to the same law, which appears to prevail throughout the Universe, that nothing shall be unnecessarily complicated. 


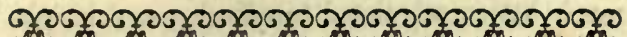

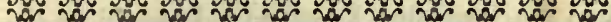

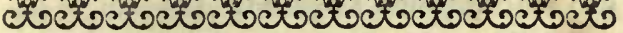

\section{CONCLUSION.}

7 HE great Linnæus, to whom the whole 1 race of naturalists must ever feel largely indebted, was the first who struck out a method that has permanently continued, for the classification of plants. This system (of which the great outlines or classes are given in a tabular view in the Appendix (A),) is grounded on the arrangements of the reproductive organs, and although it is in a great measure artificial, yet nevertheless it is so practically useful, that it has hitherto maintained its ground, and may probably continue to do so in great measure, although there are serious objections to it; chiefly because, being artificial, it does not lead a student to the knowledge of the properties, \&c. of plants, but only enables him to identify and arrange them. A sense of the insufficiency of this method has led modern systematists to form a classification, called the Natural System, because founded on the natural affinities, characters, and habits of plants, which is 
much better caleulated to afford a real insight into the Vegetable Kingdom. It would be impracticable within the limits of a work like the present, to give any detailed account of either system, especially of the natural arrangement, whose characters, not being arbitrary, require in order to be understood at all, a fulness of description inconsistent with brevity. Neither would such an account of botanical systems come within the twofold object of this little treatise, whose aim is to give the reader such an acquaintance with the wonderful structure of a large part of the world around him, as may enhanee his pleasure in contemplating it; and still more to draw his attention to that unity of purpose, palpable in the whole provision for the sustenance and eomfort of all his fellow inhabitants on our earth. If this work and its predecessor on Organic Chemistry, have been read attentively, it will have been seen that water, the soil of the earth, and the action of the air, furnish the materials from which plants obtain their nourishment; that without their intervention, the whole inferior animal race would have been destitute of food; and that man not only obtains a large portion of his sustenance immediately from them, but that they serve to elabo- 
rate such matter from the inorganic substances around them, as is then, and not till then, capable of affording him the sort of food he needs, whether derived directly from the plants themselves, or furnished by them indirectly through the animals they support, and on whom he depends for nutriment. Who can look on the principal constituents of plants, i. e. carbon, oxygen, hydrogen, and nitrogen, and contemplate their gradual transformation into vegetable albumen, and vegetable caseine,* or on any of the elementary forms of the nitrogenized compounds, so absolutely essential, directly or indirectly, to animal life, without feeling that nothing stands alone in this world, but that "the chain holds on, and where it ends, unknown." And even should it also occur to the mind, that the same process ceases not with us, but that these human bodies, thus marvellously made and nourished, are, even the organs by which the high functions of the brain are performed, material and perishable, and that "we feed ourselves to feed the worms," and, being dust, return literally to that dust again; let us not pause on the threshold of the argument, where

" "Introduction to Organic Chemistry," p. 33. 
despondency might await us, but go boldly on through the portal, and calmly consider what deduction we may draw, by the simple light of reason, from this undeniable truth. We see that every thing around us here, when it has accomplished the end of its being, is not annihilated, but only transformed into some other state, in which it still continues to work out the will of Him who created it: every material thing perfectly fulfils its destined purpose; but Man has that within which assures him that here he neither is nor does all that the soul could be and perform, were it disencumbered of the body in its present grosser state. Has he not then the strongest reason to confide in Him who gave that body for good purposes here, that $\mathrm{He}$ will at its dissolution, still make it subservient to his wise intentions, and after he separates it from its present union with the soul, will assuredly place bis rational creature in a condition to be and to do all for which that creature was made? Man would then no longer be the exception to the rest of sentient beings ; their wishes and desires are so arranged, that the means of their gratification are within their reach on earth; we, on the contrary, feel aspirations which never can be fully gratified here, 
and whose very existence foreshows a time when they will have their fruition. The moral consequence we may draw from this is almost too obvious to require notice. If we look forward to a state in which the body shall be so changed that its present enjoyments can exist no more, while those of the soul shall last for ever, how important is it that the Will, which triumphs over every thing that is material in us, should be so regulated, that when that state arrives, it may not long for those earthly pleasures which are gone to return no more, but may have already anticipated in hope the reality it shall then experience. The wise of old, though but dimly perceiving what is assured to us under the pledge and seal of God himself, could yet draw the right inference from those dim perceptions. When in the varied phases of the butterfly's frail life they saw prefigured their own future destiny, they could urge their disciples to purify the soul, and fit it for companionship with eternal Love. In the grain of wheat apparently perishing in the earth, but springing up in due season in a form "the same, and yet another," the Apostle found a similar correspondence with our lot: all can see the appropriateness and beauty of the comparison, 
may all likewise take to heart the Apostle's argument, and having this hope may they continue "steadfast and immoveable" in all that is good, knowing beyond all doubt or cavil, that their labour shall not be in vain.

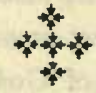




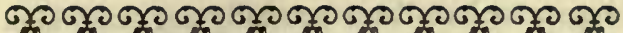 a}

\section{APPENDIX A.}

THE subject of local circulations has been 1 so clearly handled by Professor Henslow, and is in itself so important a physiological fact, that no apology is necessary for transferring his account of the matter to these pages, which is here done in a somewhat abridged form.

"In the ascent, descent, and general transfusion of the sap, we can trace the operation of physical causes modifying and controlling to a considerable extent, if, indeed, they do not originate and entirely regulate those movements. We have now to describe a more remarkable movement of the juices of some plants, which more decidedly evinces a vital action. This movement consists in a constant rotation of the fluid contained in their vesicles or tubes, and rendered apparent by the presence of minute globules of vegetable matter floating in it. The original discovery of this phenomenon was made about a century ago by Corti, who first observed it in the Caulinia fragilis, a maritime plant found on the shores of Italy. His observations 
appear to have been generally neglected until lately, when the re-discovery of the phenomenon in other plants, has excited the attention of botanists .... We shall explain the phenomenon as it may be seen in the Chara with a leus of about the tenth of an inch focal distance, or even of less power."

"In the genus Nitella" (a section of the Chara, and which is to be preferred to the true Chara, from the superior transparency of its tubes) " the stems consist of single, jointed tubes. At the joints of the stem are whorls of branches, composed also of short tubes, in each of which the same rotation of the contained fluid may be seen. If an entire tube occupying the space between two joints, be placed under the microscope, its inner surface appears to be studded with minute green granules, arranged in lines, which wind in a spiral direction from one extremity to the other. They are studded over the whole of the interior, with the exception of two narrow spaces on opposite sides of the tube, forming two spiral lines from end to end. The globules of transparent gelatinous matter dispersed through the fluid are in constant motion, being directed by a current up one side of the tube, and back again by the other. The course of this current is regulated by the spiral arrangement of the granules, and it moves in opposite 
directions, on contrary sides of the clear spaces on the minor surface of the tube. The rotation continues in a detached portion, for several days; and if the tube is tied at intervals between the joints, the fluid between two ligaments still continues to circulate, even though the extremities of the tube should be cut away. The motion here described is precisely similar to what takes place in the tubes of Corallines, and must unquestionably be considered as the result of a vital action." Although the circulation in the laticiferous vessels is denied by many of the most distinguished physiologists, yet the subject is so curious, and so well worthy of farther investigation that it is deemed advisable to add the account of it also in Prof. Henslow's words.

"It was in the year 1820, that a distinguished naturalist, M. Schultes, first announced his discovery of a peculiar movement in the juices of plants, which more nearly resembles the circulation of the blood in animals than any thing which had formerly been observed. .... The liquid, whose movement is described, and which M. Schultes terms the 'latex,' is sometimes transparent and colorless, but in many cases opaque, and either milk-white, yellow, red, orange, or brown. . . This liquid is considered to be the proper juice of the plant, secreted from the crude sap in the intercellular passages, and con- 
sequently analogous to the blood of animals, as was long since suggested by Grew; who further likened the lymphatic, or crude sap, to their chyle. It is contained in delicate transparent membranous tubes, which become cylindrical when isolated, but when pressed together in bundles, assume a polygonal shape. ... The movement of the latex can be witnessed only in those parts which happen to be very transparent, and it has not been actually seen in many plants. The Ficus elastica, Chelidonium majus, and Alisma plantago, are the species upon which most of the observations hitherto recorded have been made. Distinct currents are observed traversing the vital vessels, and passing through the lateral connecting tubes or branches, into the principal channels. These currents follow no one determinate course, but are very inconstant in their direction, some proceeding up, and others down, some to the right, and others to the left; the motion occasionally stopping suddenly, and then recommencing. . . . The effect does not scem to depend upon a contractile power of the tubes, because the latex flows chiefly or entirely from one end of a tube, even when it has an orifice open at both extremities. The appearance is especially analogous to the circulation of some of the lowest tribes of animals, as in the Diplozoon paradoxum, which may be divided into two 
parts, and the blood will continue to circulate for three or four hours in each. By a strong electric shock, the force by which the latex is propelled, is paralysed, and its motion arrested." (Henslow's Principles of Botany, p. 207, et seq.)

\section{B.}

\section{ANALYSIS OF THE LINNÆAN CLASSES.}

FROM RALF'S " ANALYSIS OF THE BRITISH FLORA."

$1\left\{\begin{array}{l}\text { Neither stamens nor pistils } \\ \text { Stamens and pistils ........... }\end{array}\right.$ Cryptogamia (24.)

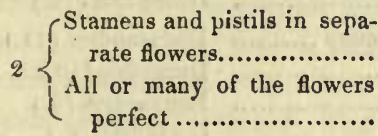
2.

3.

4.

$3\left\{\begin{array}{r}\text { Barren and fertile flowers on } \\ \text { different plants ............ } \\ \text { Barren and fertile flowers on } \\ \text { the same plants ............ }\end{array}\right.$ Diøcia (22.)

Monøcia (21.)

(Some flowers with pistils only, and a perianth unlike that of the united or of the barren flowers. Polygamia (23.)

Flowers with both stamens and pistils, or with similar

perianths....................... 


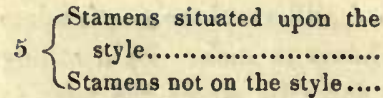

Flowers compound; (anthers

$6\left\{\begin{array}{r}5, \text { united) .................... } \\ \text { Flowers not compound ...... }\end{array}\right.$

$7\left\{\begin{array}{r}\text { Filaments united in one or } \\ \text { more sets..................... } \\ \text { Filaments not united .......... }\end{array}\right.$

Filaments united in one set

8 Filaments united in two sets

Filaments united in more

than two sets.

9 Stamens 16 or more

Stamens 15 or fewer ..........

Stamens inserted into the re-

Stamens inserted into the calyx

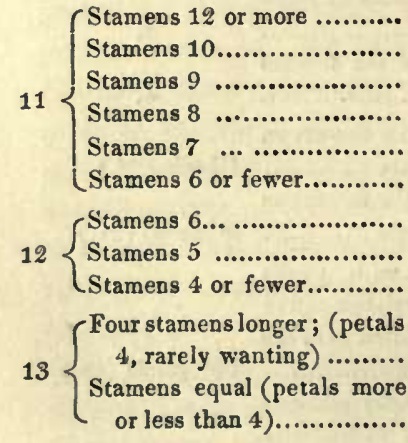

S Stamens 4

\{ Stamens 3 or fewer ..........
Gynandria (20.)

6.

Syngenesia (19.)

7.

8.

9.

Monadelphia (16.)

Diadelphia (17.)

Polyadelphia (18.)

10.

11.

Polyandria (13.)

Icosandria (12.)

Dodecandria (11.)

Decandria (10.)

Enneandria (9.)

Octandria (8.)

Heptandria (7.)

12.

13.

Pentandria (5.)

14.

Tetradynamia (15.)

Hexandria (6.)

15.

16. 
$15\{$ Two stamens longer .......... Didynamia (14.)

\{ Stamens equal................. Tetrandria (4.)

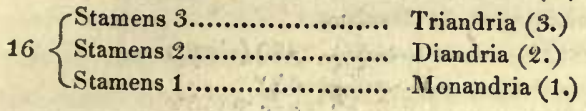

The above form is given in preference to a mere enumeration of the Linnæan Classes as being more useful and instructive. It will at once be perceived that if it is wished to know what class any plant belongs to, we must in the first instance observe whether it has stamens or pistils, if it has neither, it is one of the Cryptogamia, and our point is ascertained at once. If it have stamens and pistils we are referred to No. 2, and, accordingly, as the stamens and pistils are, or are not, on the same flower, we are to turn to No. 3 or 4 , and so on till we have completed our search. Such an analysis is of great practical utility. The number of each class in Linnæus' arrangement, is given at the end of each in a parenthesis.

\section{C.}

A $T$ the end of a chapter on the longevity of 1 trees, in which M. De Candolle fully shows his grounds for concluding their ages to be what he has stated, he gives the following table of some of the most remarkable in the world. 


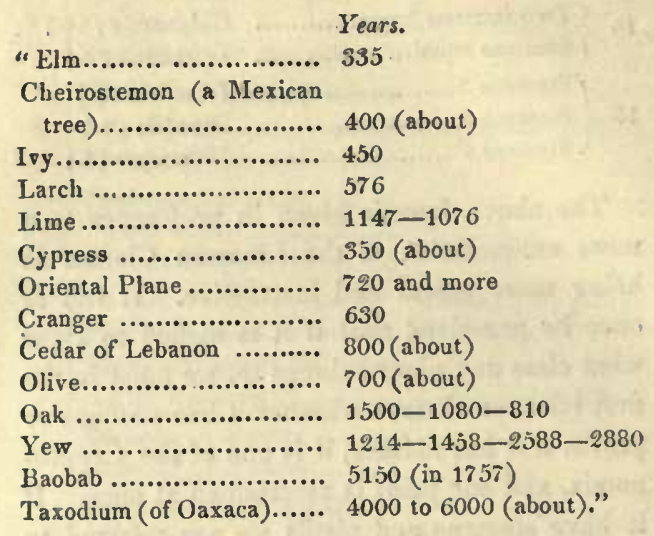

"The Baobab (Adansonia digitata) is the most celebrated example of extreme longevity that has yet been observed with precision. It bears in its native country a name which signifies $a$ thousand years, and contrary to custom, this name is short of the truth." *

The following notice respecting this species of tree has been kindly furnished by a friend. "Adanson's own statement concerning the Baobab, and his reasonings upon it amount to this. He saw, in one of the two Magdalen Islands, two Baobabs, bearing European naines, some of which were very distinctly of the date of the

- De Candolle, Physiologie Végétale, tom. ii. P; 1003. 
16th and 15th centuries,* and others somewhat confusedly ('assez confusément') of the 14th; years having effaced, or filled up the greater part of the characters. These were probably the same trees which Thevet mentions having seen in those islands, in his voyage to the Antarctic Seas in 1555 (in which, however, no notice is taken either of the size of the trees, or of inscriptions on them). These characters were six inches at the utmost in length, and not so much as two feet in width, being about the eighth part of the circumference of the trunk, from which Adanson concluded that they had not been cut while the trees were young. Neglecting the date of the 14th century, and taking that of the 15 th, which is very distinct, he holds it to be evident that, if these trees have been two centuries in gaining six feet in diameter, they would be at least eight in acquiring twentyfive feet. But experience teaches that trees grow rapidly at first, afterwards more slowly, and finally cease to increase in diameter, when the tree has attained the size usual to its species. Adanson knew from observation, that the

* It seems clear that Adanson in speaking of the 14th, 15 th, and 16 th centuries, really means the 15 th, 16 th, and 17 th, inasmuch as he in one place carefully reckons from the date of the 15 th century to the year 1749 , as a period of two centuries. 
Baobab in its first year, measured from an inch to an inch and a half in diameter; that at the end of ten years it reached a foot in diameter; and at the end of twenty, about a foot and a half. These data, he adds, are insufficient for any precise determination; he, therefore, limits himself to suspecting that the growth of the Baobab, which is very slow with relation to its monstrous size (of twenty-five feet diameter) must continue for several thousand years, and perhaps ascend to the time of the deluge; so that we have good reason to believe that the Baobab is the most ancient of the living monuments which the terrestrial globe can furnish. These particulars are given in a 'Déscription d'un Arbre d'un nouveau genre, appelé Baobab, observé au Sénégal,' published by Adanson in the Mémoires de l'Académie des Sciences, for 1761, where he also states the circumference of the tree as reaching to sixty-five feet, or even seventy-seven and a half feet, making its diameter somewhat less than twenty-five fect. In his 'Voyage au Sénégal,' he speaks, p. 54-5, of having measured two trunks of sixty-five feet and sixty-three feet circumference; and again, $p$. 104, of two others measuring seventy-six and seventy-seven feet, but it does not appear that these were the trunks on which the names were cut. 
"The only certain way of discovering the age of trees of temperate and northern climates is by cutting them down, and counting their annual layers, but even this method becomes uncertain with respect to the trees of tropical countries, in which the layers are frequently very indistinct, and in which they are also, in some instances, repeated several times in the year.

"With respect to the Baobab, if its age be doubtful, its size at least has not been exaggerated. M. Perottet states in the "Flore de Sénégambie," that Baobabs are frequently to be found measuring from seventy to ninety feet in circumference. He promises a memoir on their mode of growth, but the writer of this is not aware if he has yet published it.

"The subject of inscriptions in trees, (originally cut through the bark, and having their woody portion covered up by successive annual layers) is a very curious one. It has been the subject of numerous memoirs, of which a list is given in the Catalogue of Sir Joseph Banks's Library."

Although England has no trees whose usual size can compete with that of the gigantic Baobab above mentioned, some of her yews and oaks are as worthy of record, and approach more nearly to it in dimensions, than is perhaps. 
generally known or remembered. Evelyn, after mentioning several giants of the forests, both of his own and of foreign countries, says,

"To these I might add a yew tree in the churchyard of Crowhurst, in the county of Surrey, which I am told is ten yards in compass; but especially that superannuated yew tree now growing in Braburne churchyard, not far from Scott's Hall, in Kent; which being fifty-eight feet, eleven inches, in the circumference, will bear near twenty feet diameter, as it was measured first by myself imperfectly, and then more exactly for me, by order of the late Right Honourable Sir George Carteret, Vice Chamberlain to his Majesty, and late Treasurer of the Navy: not to mention the goodly planks, and other considerable pieces of squared and clear timber, which $I$ observed to lie about it, that had been hewed and sawn out of some of the arms only, torn from it by impetuous winds. Such another monster, I am informed, is also to be seen in Sutton churchyard, near Winchester." * In a note, the Editor of the Sylva (Dr. A. Hunter) gives the following account of a most remarkable oak, actually rivalling the Baobab in girth,-it is accompanied by an engrav-

* Sylva. Vol. ii. Book S, Ch. S, p. 195. Hunter's ed. 
ing. " $\mathrm{My}$ ingenious friend, Mr. Marsham, informs me that there is now growing in Holt Forest, near Bentley, a vigorous and healthy oak, which at five feet from the ground, measures thirty-thrce feet, eight inches, in girt; however, neither this, nor any of the oaks mentioned by Mr. Evelyn, bear any proportion to one growing at Cowthorpe, near Wetherby, upon an estate belonging to the Right Hon. Lady Stourton. The annexed plate is taken from a drawing made upon the spot in the year 1776. The dimensions are almost incredible. Within three feet of the surface it measures sixteen yards in circumference, and close by the ground, twenty-six yards. Its height is about eighty feet, and its principal limb extends sixteen yards from the bole. Throughout the whole tree, the foliage is extremely thin, so that the anatomy of the ancient branches may be distinctly seen in the height of summer."*

If we may descend from the lordly oak to so humble a plant as a radish, the reader may perhaps be amused by the following notice of an enormous specimen of this vegetable, also mentioned by Evelyn, in his "Terra. A Philosophical Discourse of Earth, relating to the Culture and Improvement of it for Vegetation, and

* Ibid. p. 197. 
the Propagation of Plants, as it was presented to the Royal Society."- "Peter Hondius tells us (in his book entitled Dapes inemple) that by the sole application of sheep's dung he produced a raddish root in his garden as big as half a man's middle, which being hung up for some time in a butcher's shop, people took for an hog." The date of this paper is Ap. 29. 1675. It is a curious mixture of valuable information with the crude speculations that formed much of the, so called, science of that day - yet giving evidence of the value of the new light that had been already thrown on the path of knowledge by directing the attention to experimental research, of which it contains a record exhibiting much patient investigation. It is also an interesting document, being one of the very early communications to the Royal Society, during the Presidency of Lord Brouncker. A few further extracts from it may be entertaining, and if they induce us of the 19th century to smile at the strange notions which such men as Lord Bacon and John Evelyn could think worthy of notice, the smile will be any thing rather than a sneer, and will be quickly followed by a feeling of gratitude to those great men, who, born in days of comparative ignorance, were nevertheless so far beyond the times in which they lived, that they could perceive and point out the 
very course which has obtained for science the enlarged boundary she now possesses; and to the Society which first made the cause of science a national question, and under whose auspices England has attained an eminence which all her sons must ardently pray she may never lose.

A passage near the commencement of the "Discourse of Earth," is so characteristic of the style of writing of the period, that it is worth extracting. After a modest disclaiming of his own powers, Evelyn goes on to say, "There are few here I presume, who know not upon how innocent and humble a subject $I$ have long since diverted my thoughts; and, therefore, I hope they will not be displeased, or think it unworthy of their patience, if from their more sublime and noble speculations (and which do often carry them to converse among the brighter orbs and heavenly bodies) they descend awhile, and fix their eyes upon the earth, which I make the present argument of my discourse. I had once indeed, pitched upon a subject of somewhat of a more brisk and lively nature; for what is there in nature so sluggish and dull as earth? What more spiritual and active than regetation, and what the earth produces? But this, as a province becoming a more steady hand and penetrating wit than mine to cultivate, (un- 
less where it transitorily comes in my way to speak of salts and ferments) I leave to those of this learned society, who have already given such admirable essays of what they will be more able to accomplish upon that useful and curious theme; and, therefore, I beg leave that I may confine myself to my more proper element, the earth, which though the lowest and most inferior of them all, yet is so subservient and necessary to vegetation, that without it, there could hardly be any such thing in nature." He then gives a long account of different strata of earths, \&c. in which some of the phraseology sounds strangely to modern ears-for instance, "marsh-earth," is said to be "the most churlish," and marl, "of a cold, sad nature." The two following passages are among those which cannot be read without a smile, "If, upon excavating a pit, the mould you exhaust do more than fill it again, Virgil tells us 'tis a good augury; upon which Laurembergius affirms, that at Wellemberg, in Germany, where the mould lies so close, as it does not replenish the foss out of which it has been dug, the corn which is sown in that country soon degenerates into rye; and what is still more remarkable, that the rye sown in Thuringia (where the earth is less compacted) reverts, after three crops, to be wheat again." 
"My Lord Bacon directs to the observation of the rainbow, where its extremity seems to rest, as pointing to a more roscid and fertile mould; but this, I conceive, may be very fallacious, it having two horns, or bases, which are ever opposite."

Among such strange ideas, which, however, bear but a very trifling proportion to the bulk of practical information which was probably new and valuable to the agriculturist of those days, there is the dawning of a true knowledge of Vegetable Physiology. The indispensable importance of water, the probable influence of the atmosphere, both on the plants themselves, and on the soil, the strong suspicion at least, " that plants do more than obscurely respire, and exercise a kind of peristaltic motion," are among the indications of an approach to truth, and when we remember that about this time Grew was employed on the "Anatomy of Plants," we may fairly trace back to these days the beginning of the Science, properly so called, which is the subject of this little book; nor can better words be found with which to conclude it, than those of Evelyn, speaking of the "Groves and Woods,"- " But I cease to expatiate farther on these wonders, that I may not anticipate the pleasures with which the serious contemplator on those stupendous works of Nature (or rather 
God of Nature) will find himself wrapt and transported, were his conteniplations only applied to the production of a single tree." *

* Sylva, Book 4, p. 343.

FINIS.

C. WHITINGHAN, CHISWICh. 


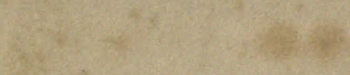

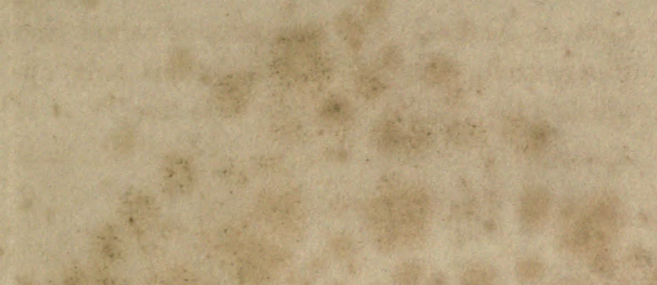

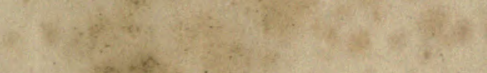

स.

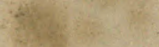

(4.

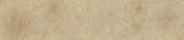

25

25,

3

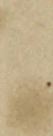

$x^{2}$ ingents

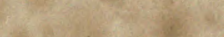

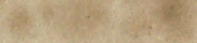

(x)

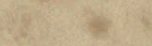
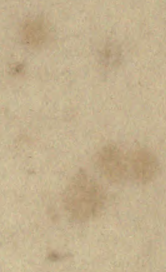

1.
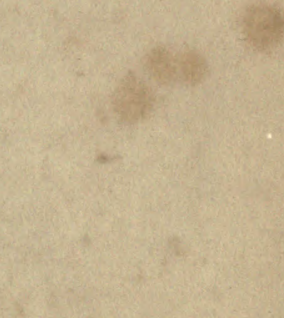

3
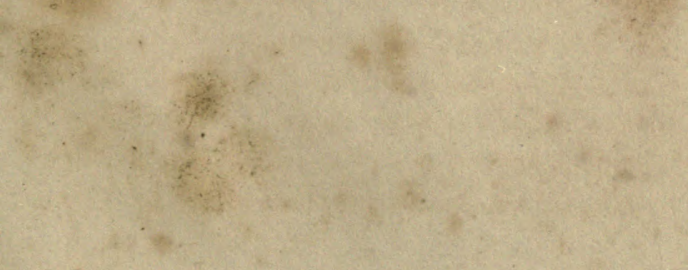

UC SOUTHERN REGIONAL LIBRARY FACILITY

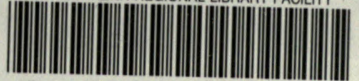
A 0000495192 
